Review

\title{
Advanced vapour sensing materials: Existing and latent to acoustic wave sensors for VOCs detection as the potential exhaled breath biomarkers for lung cancer
}

\author{
Nurul Liyana Lukman Hekiem ${ }^{\mathrm{a}}$, Aliza Aini Md Ralib ${ }^{\mathrm{a}, *}$, Maziati Akmal bt Mat Hattar ${ }^{\mathrm{b}}$, \\ Farah B. Ahmad ${ }^{\mathrm{c}}$, Anis Nurashikin Nordin ${ }^{\mathrm{a}}$, Rosminazuin Ab Rahim ${ }^{\mathrm{a}}$, \\ Nor Farahidah Za'bah ${ }^{\mathrm{a}}$ \\ ${ }^{a}$ Department of Electrical and Computer Engineering, International Islamic University Malaysia, 53100, Kuala Lumpur, Malaysia \\ b Science Engineering Department, International Islamic University Malaysia, 53100, Kuala Lumpur, Malaysia \\ c Department of Biotechology Engineering, International Islamic University Malaysia, 53100, Kuala Lumpur, Malaysia
}

\section{A R T I C L E I N F O}

\section{Article history:}

Received 5 August 2020

Received in revised form 29 January 2021

Accepted 24 April 2021

Available online 29 April 2021

\section{Keywords:}

Lung cancer

Breath analysis

Volatile organic compound

Acoustic wave sensor

Biopolymer

Composites

\begin{abstract}
A B S T R A C T
Lung cancer is the leading cause of death worldwide and has a significant impact on public health across society. Among all types of cancer, lung cancer is typically silent and it is commonly diagnosed at a later stage where treatment is rarely achievable. There is an urgent need for the development of the early diagnosis of lung cancer for an improved survival rate. Preliminary research shows that lung cancer is accompanied by increased oxidative stress which generates volatile organic compounds (VOCs). Hence, breath analysis offers the most promising solution for the early diagnosis of lung cancer as it is noninvasive and radiation free. Potential VOCs biomarkers in exhaled breath associated with oxidative stress and lipid peroxidation have been discussed to provide a quick approach to the diagnosis of lung cancer. Although gas chromatography-mass spectroscopy (GC-MS) able to analyze the VOCs biomarker, it is bulky, high cost, required expertise to handle and consumes a lot of time. Hence, the sensor-based technique provides the solution to overcome the limitation. Recently, acoustic wave sensors such as quartz crystal microbalance (QCM) and surface acoustic wave sensors (SAW) have been used to identify the presence of VOCs in various applications. This is due to its high selectivity, good reproducibility, and fast response sensing materials. The selection of vapour sensing materials plays a crucial role in developing a highly sensitive and selective and fast response acoustic wave sensors. For this purpose, various types of sensing layers from metal oxides, polymers, biopolymers and composites have been studied. We present a critical review of advanced vapour sensing materials that are primarily used in acoustic wave sensors in identifying the presence of various VOCs. Criteria to evaluate the performance of the acoustic wave sensors such as resonance frequency and sensitivity are also discussed.
\end{abstract}

(C) 2021 Elsevier B.V. All rights reserved.

\section{Contents}

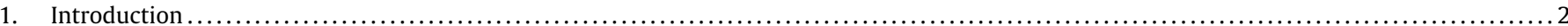

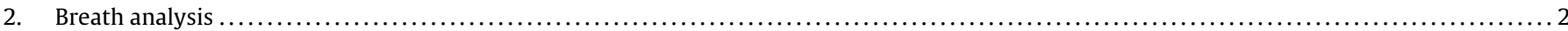

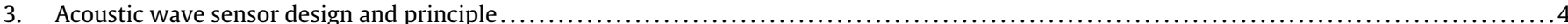

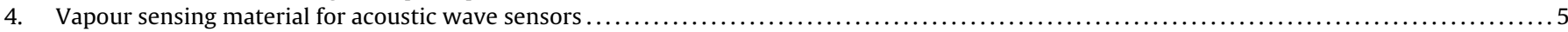

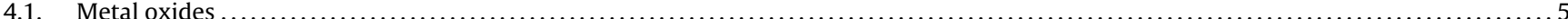

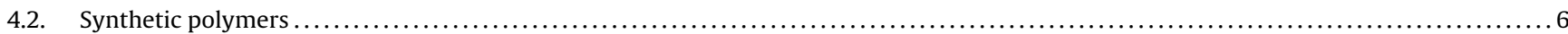

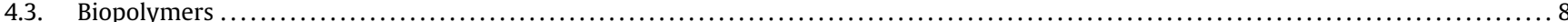

\footnotetext{
* Corresponding author.

E-mail address: alizaaini@iium.edu.my (A.A. Md Ralib).
} 


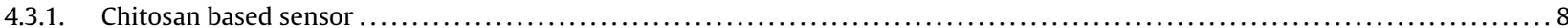

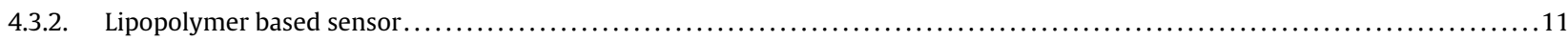

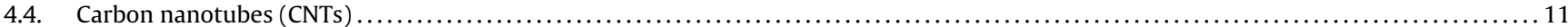

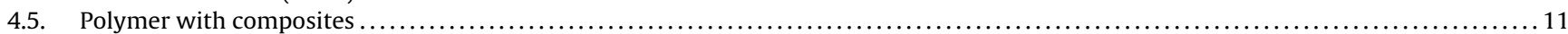

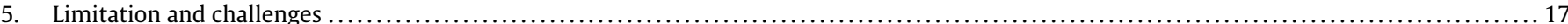

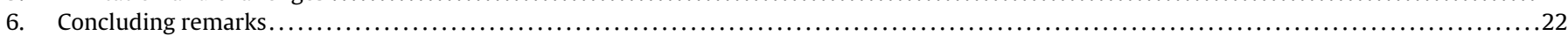

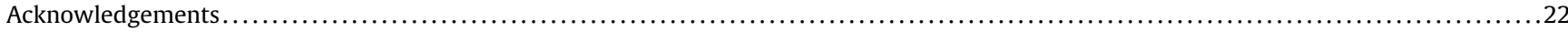

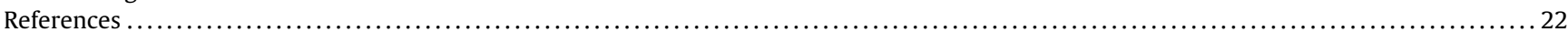

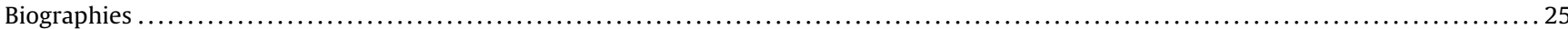

\section{Introduction}

Cancer is the leading cause of death in a society and many issues related with it have a significant impact on public health across society. According to the 2018 report from Global Lung Cancer Coalition, the lung cancer accounted for 13.3 deaths per 100,000 population in Malaysia or 4057 number of deaths from 4686 number of lung cancer diagnosed [1]. This statistical statement is indicating only about $16-17 \%$ of the lung cancer patients, survived. This information is tally to the statistical analysis done by the World Health Organisation (WHO) in 2018 where Asia portrayed the highest number of cancer cases by approximately $48 \%$ of the 18.1 million cases worldwide with $70 \%$ of death from lung cancer occurs in the low and middle income countries [2]. Several techniques that are currently in used for lung cancer detection including chest x-ray, computed tomography (CT) scan, fluorodeoxyglucosepositron emission tomography (FDG-PET), bronchoscopy, and lung biopsy [3]. However, these detection techniques are expensive, invasive, time consuming [4], bulky [5], required expertise to handle it [6-8] and relatively large [9]. Besides, positron emission tomography (PET) is a current practice for lung cancer detection. Yet, the screening cost is very high [10]. There is an increasing concern that the early detection of lung cancer can increase the number of lung cancer survival. Exhaled breath analysis has been introduced for early lung cancer diagnosis based on VOCs biomarkers. Detection of disease using exhaled breath is becoming an increasingly extensive non-invasive diagnostic tool to assess information on the health status. By measuring the concentration of endogenous volatile organic compound VOCs, it allows real time alternative for early diagnosis of lung cancer [11]. In recent studies, some common chemicals recognized as VOC biomarkers of lung cancer are styrene, decane, isoprene, benzene, 1 - hexane and propyl benzene [11]. Studies showed VOCs from breath samples have high potential for rapid and non-invasive screening and disease detection [12]. Breath analysis has the advantages of being non- invasive, highly sensitive, simple and potentially cheap [13]. This benefit strengthens the need of having an alternative measure of a non-intrusive, portable and effective sensor for lung cancer. Moreover, there are several technology in gas analysis field; chemo-resistive device, gas chromatography- mass spectrometry (GC-MS) [14], as well as the sensor based diagnosis which is currently still developing. Although gas chromatography - mass spectroscopy (GC-MS) able to analyse the VOCs biomarker, it is bulky, high cost, required expertise and consume a lot of time. Hence, sensor-based technique provides the solution to overcome the limitation. Gas sensing devices can detect and identify the presence of VOCs biomarkers for early detection of lung cancer. Current sensing techniques introduced for breath analysis are surface acoustic wave (SAW) sensor [15-18], quartz crystal microbalance (QCM) sensor [19,20], optical sensor, gold nanoparticle (GNP) sensor [21], colorimetric sensor array [22], metal oxide sensor [23] and conducting polymer composited (CPC) sensor [13]. Among them, the acoustic wave sensor such as QCM and SAW sensors are known to have several advantages such as high sensitivity, fast response and good stability [24]. However, despite the versatility of using QCM and SAW sensor in vapour recognition purposes, a critical issue on the sensing materials used still needs to be investigated further.

The issue arises from the current innovated acoustic wave sensors that are at high risk in misinterpreting the frequency change due to the variation in mass density, mechanical stiffness, viscosity, electric and dielectric properties [25]. The reproducibility and the reliability of the sensors are mainly depending on the homogeneity of the sensing layers and detection limits. This is due to the conventional sensing materials present such as metal oxide, and carbon nanotubes on their own are still lacking in providing the finest modification to the acoustic wave sensors for a thorough vapour recognition. Hence, further work is required to cater these challenges. One of the strategies to overcome the drawback in the application of acoustic wave sensors is through the use of alternative sensing materials. There are numerous types of sensing materials with biopolymer that have attracted the attention of recent research work. Therefore, the aim of this paper is to review the vapour sensing materials using acoustic wave sensor for VOCs detection as the potential exhaled breath biomarkers for early detection of lung cancer.

The state of art of existing and various types of sensing materials for acoustic wave sensor such as metal oxides, polymers and composites will be highlighted in this paper. This solution is more effective in way that it is making the sensors to be more sensitive, with faster response time and high mobility compared to the traditional material. Criteria to evaluate the performance of the gas sensors in terms of resonance frequency and sensitivity are also outlined.

This paper is organized into sections where the following section (Section 2) describes and explains the significance of breath analysis for lung cancer detection and the biomarkers involved. Section 3 focuses on the use of acoustic wave sensors, with the basic principle of piezoelectricity along with the related work on biopolymer based QCM sensor whilst Section 4 discusses the findings from the work mentioned throughout the review.

\section{Breath analysis}

Breath analysis is a method of gaining information on the clinical state of an individual by monitoring the volatile organic compounds (VOCs) present in the exhaled breath. In extensive definition, VOCs are of carbon-based compounds in which is readily evaporated at room temperature. In medical purposes, VOCs are a cocktail of organic compounds present in the content of human breath to be used as the biomarkers [26]. For instance, acetone, a VOC, is highly related to diabetes detection. Patients with diabetes are more likely to have greater percentage of acetone in comparison to a healthy person [26]. The patients with lung cancer undergo VOCs alteration in their body system. Such alteration may cause the occurrence of oxidative stress from the presence of free radicals and reactive oxygen species (ROS), gene mutation or rearrangement, Warburg effect and apoptosis [27]. 


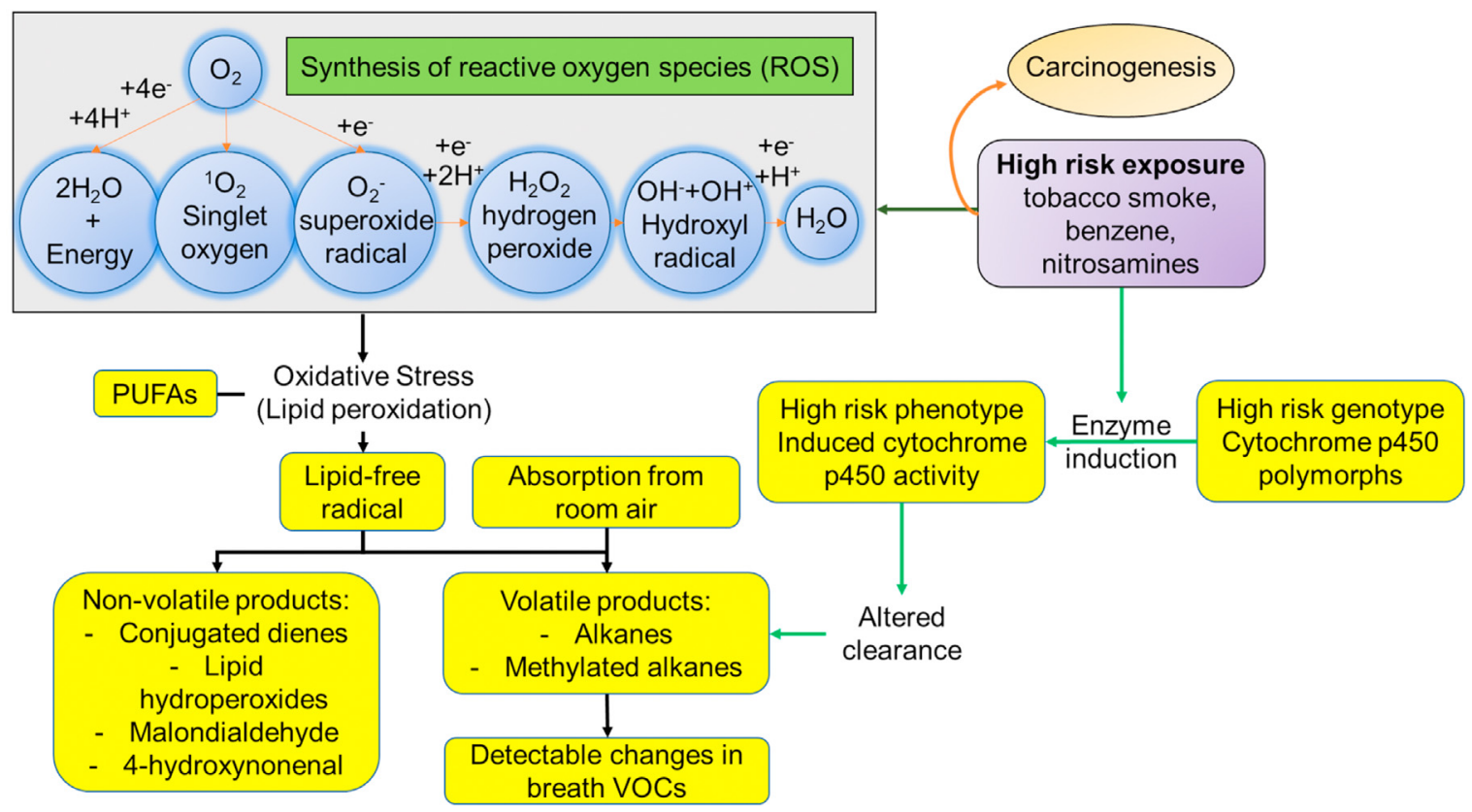

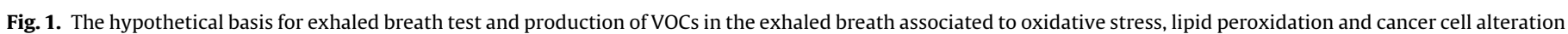
due to high exposure to carcinogenic substances [30].

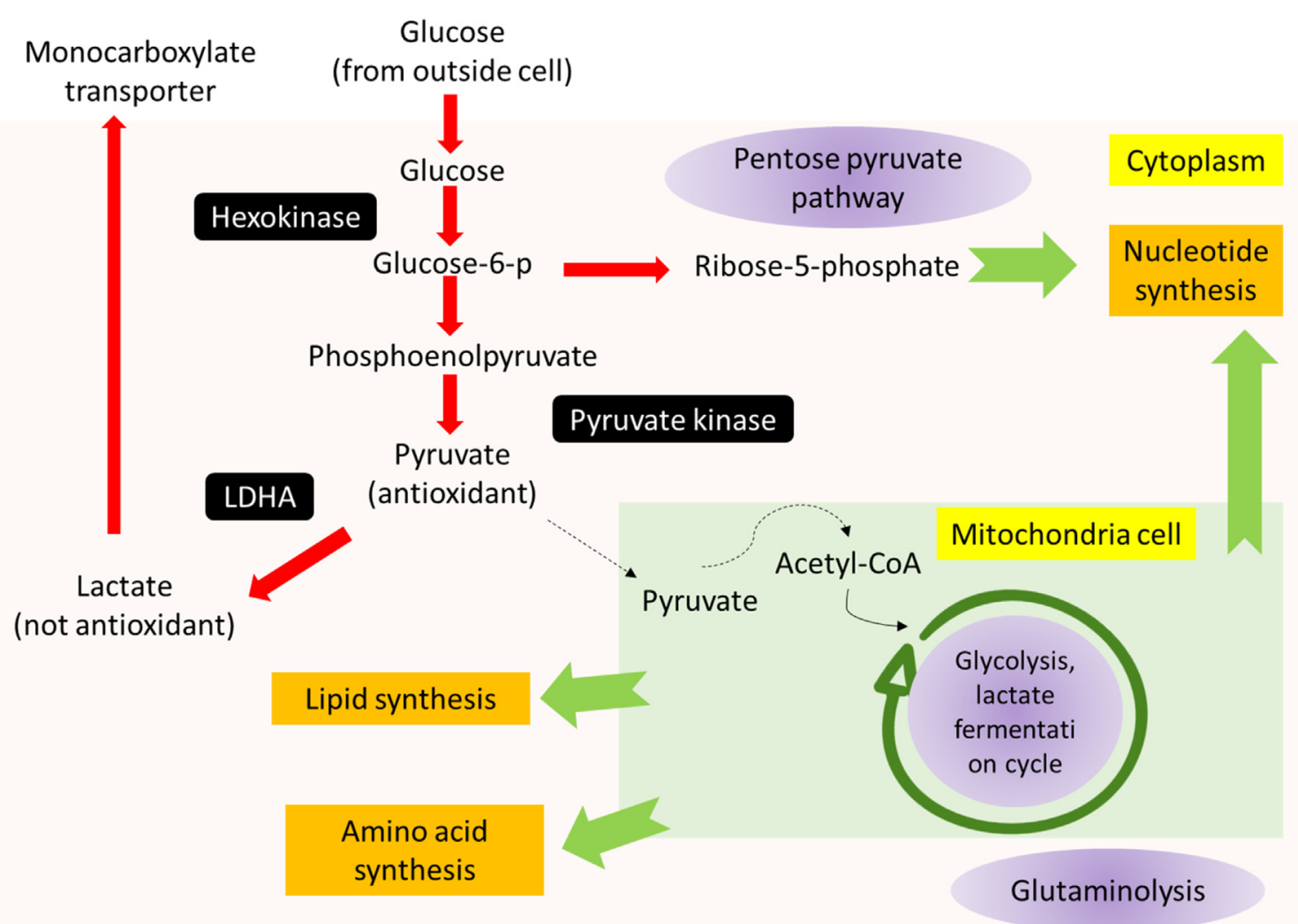

Fig. 2. Illustration of Warburg effect on a typical mammalian cell [37].

A. Amann et al. highlighted the effect of oxidative stress on the rapid growth of cancerous cells in lung $[28,29]$. People with cancer, tend to have ROS in excess leading to oxidative stress. Oxidative stress will cause lipid peroxidation resulting in the alteration of VOCs which is then secreted through the exhaled breath. Fig. 1 summarises the hypothetical basis for exhaled breath test and production of VOCs in the exhaled breath associated to oxidative stress and lipid peroxidation [30]. The VOCs that are commonly associated to oxidative stress and lipid peroxidation are VOCs with hydrocarbons; decane, and heptane as well as aldehydes; formaldehyde and hexanal [31]. Aldehydes can be both endogenous and exogenous sources. Exogenous source occurred when humans are exposed to formaldehydes from household products made up from woods, cosmetic, engines and cigarette smoke or second-hand-smokers 
Table 1

Summary of the lung cancer biomarkers from previous work.

\begin{tabular}{lll}
\hline Author(s) & VOCs & VOCs functional groups \\
\hline & Propanol & Alcohol \\
& Isoprene, pentane, & Alkanes/ alkenes \\
(Jia et al.,2019) [38] & Acetone & Ketone \\
& Hexanal & Aldehydes \\
& Toluene, benzene, & Aromatics \\
& ethyl benzene & \\
& Acetone & Ketone \\
(Lawal \& Wallace, & ethanol, & Alcohol \\
2014) [140] & 3-methyl-1butanol & \\
& 2-butanone & Ketone \\
& 1-propanol & Alcohol \\
(Crucitti, Longo, Rocco, & Isoprene & Alkene \\
\& Rocco, 2018) [141] & Ethylbenzene, styrene & Aromatics \\
& Hexanal & Aldehyde \\
& Acetone & Ketone \\
(Masuda, Kato, Kida, \& & Butanal & \\
Otsuka, 2019) [78] & Formaldehyde & Aldehydes \\
& Acetaldehyde & \\
\hline
\end{tabular}

(SHS) [32]. Meanwhile, formaldehydes and a few other aldehydes for instance, hexanal, heptanal, acetaldehyde and propanal may be obtained endogenously as the by-products of alcohol metabolism by an enzyme known as alcohol dehydrogenase (ADH) [33,34]. Aside from the ROS effect, high exposure to carcinogenic gases may also increase the risk of enzyme induction which will then induces the alteration of cancerous cell. Some common carcinogenic gases are tobacco smoke, benzene, and nitrosamine [30]. Warburg effect related to cancer disease is briefly defined as the overdriven anaerobic glycolysis of the dysfunctional mitochondria [35,36]. It will either cause cancer cells development or rapid growth of the cancerous cells existing in the body. Fig. 2 illustrates the anaerobic glucose metabolism or Warburg effect. Depending on the situation, the biomarkers for a lung cancer patient may differ as VOCs can be obtained from both exogenous and endogenous sources. Lung cancer patients who smoked are most likely to have greater aromatic compounds such as benzene and toluene as compared to a nonsmoking patient, in which the endogenous VOCs may be a much more reliable biomarker.

VOCs can be detected in the headspace of lung cancer cells blood vessels and exhaled breath. It has been classified in six different groups; (i) alkanes and alkenes, (ii) alcohols, (iii) aldehydes, (iv) ketones, (v) nitriles and (vi) aromatics [21,31,38,39-41]. There are over 20 biomarkers for lung cancer analysed by Thriumani et al. [14]. Other literature cited that ethane, pentane, aldehydes, isopropane, and isoprene [6] are also enlisted as biomarkers.

From previous work, the identification of biomarkers for lung cancer was challenging and each work claimed to have different number of biomarkers. There is inadequate information to confirm the biomarkers for lung cancer. It is because VOC profiles are influenced by the retention of VOCs in the lungs aside from the error in breath sampling; contaminations from the collection sys- tem, expiratory flow rate, humidity and study design; diet, lifestyle, age, medication and disease stage [30]. Haick et al., highlighted that 115 reliable gases were reported as exhaled breath biomarkers [30]. Current technique used to identify the biomarkers is the gas chromatography- mass spectrometry (GCMS) [14]. This technique produces a list of molecules present in the sample. However, this detection technique is expensive, time consuming [42], not portable, required expertise to handle it [6] and relatively bulky [9]. The GCMS technique may inhibit the accessibility for most individuals to get diagnose at the early stage. Recently, QCM and SAW have been used to identify the presence of VOCs in various applications. This is due to its high selectivity, good reproducibility and fast response sensing materials. The identification of lung cancer biomarkers based on previous work are summarised in Table 1 and classified into the chemical functional groups it belongs.

\section{Acoustic wave sensor design and principle}

There are several methods for VOC sensing such as solidstate sensing method, optical, electrochemical and acoustic wave method based on mass-sensitive sensor as shown in Fig. 3. Mass sensitive sensor-based techniques includes the use of QCM and SAW will be further discussed throughout this paper.

QCM and SAW sensors are both categorised as mass sensitive sensor based on piezoelectricity transduction. The principle of piezoelectricity is applied as the sensing mechanism [43]. Piezoelectricity is defined as the ability of some piezoelectric materials to generate electrical energy when mechanical stress is applied or vice versa. The conversion of mechanical stress to electrical energy is meant to be the direct piezoelectric effect while the conversion of electrical energy to mechanical energy is known as the converse piezoelectric effect [43]. There are two types of piezoelectric crystal sensors: (i) the bulk acoustic wave (BAW) (ii) surface acoustic wave (SAW). QCM sensor is categorised as bulk acoustic wave device. The alternating electric field applied over the electrodes of the QCM sensor leads to the oscillation of the quartz crystal substrate and the transverse acoustic wave propagates through the quartz substrate. The sensor measurement is represented by frequency shifts due to the change in mass and velocity of the wave propagating through the quartz crystal substrates. Fig. 4(a) illustrates the sensing mechanism of QCM towards analyte gas. The working principle of QCM is that it converts the electrical energy to mechanical energy (acoustic wave) and reconverted at to electrical energy as the output measured. When voltage is applied to the top electrode of the QCM, the acoustic wave will be generated and propagated through the quartz piezoelectric substrate. The acoustic wave will be converted back to electrical signal as the output measured in terms of resonance frequency. For sensing purpose, the QCM will be coated with a chosen sensing layer to adsorb the presence of analyte gas. The interaction of the sensing layer with the presence of the analyte gas will cause changes in the wave amplitude and velocity due to the

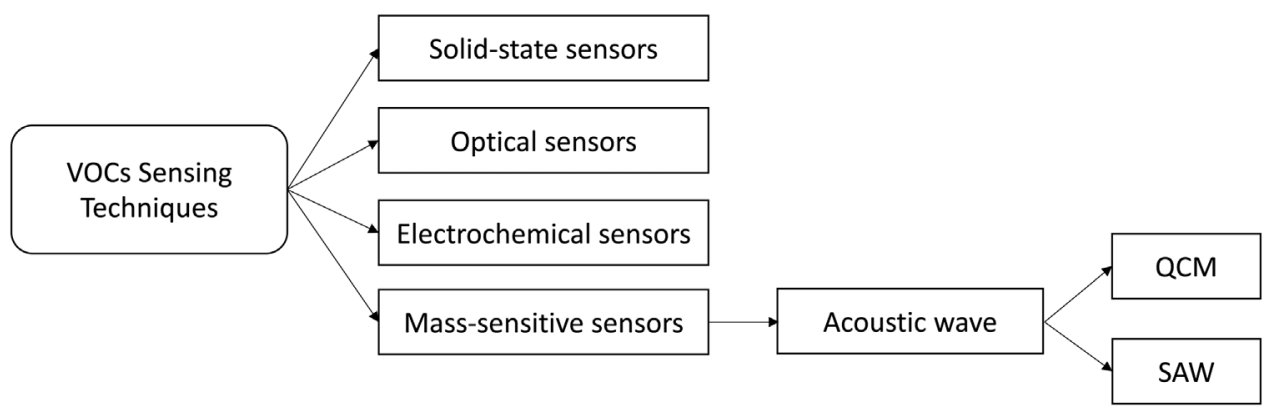

Fig. 3. Several methods in sensing VOCs. 

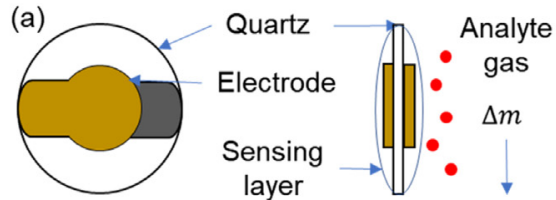

$\Delta f$
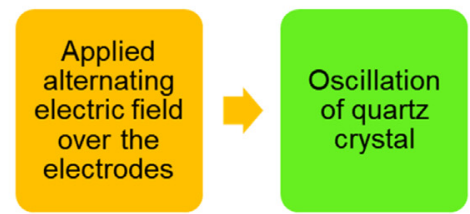
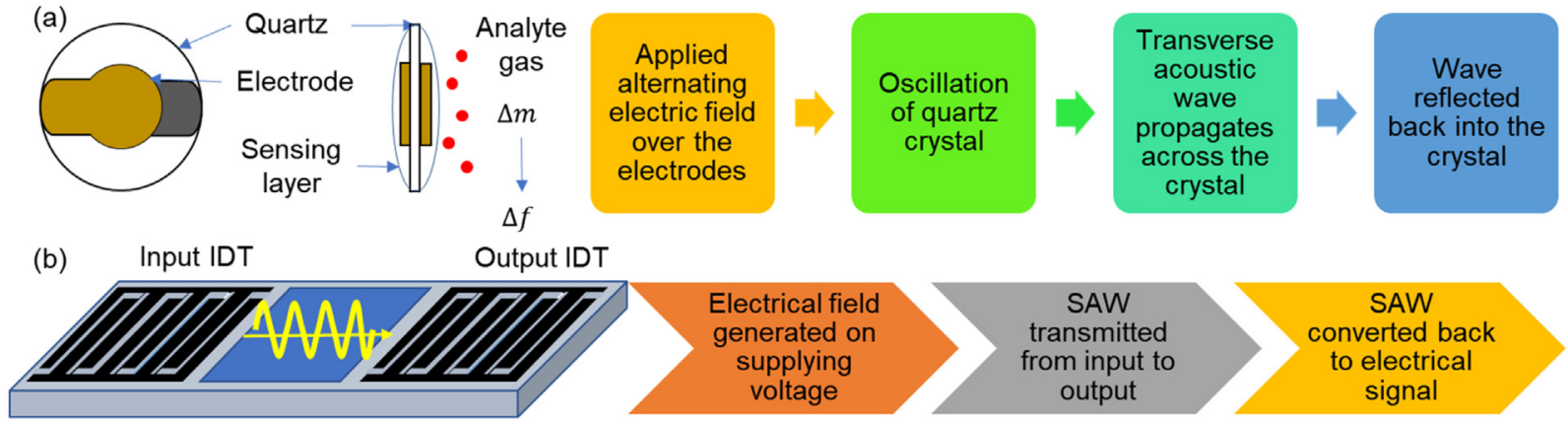

\section{SAW} converted back to electrical signal

Fig. 4. Sensing mechanism for detection using (a) QCM sensor and (b) SAW sensor.

Table 2

Summary of the key parameters for both QCM and SAW sensors.

\begin{tabular}{lll}
\hline Sensor & QCM & SAW \\
\hline Resonant frequency & $f=\frac{v}{2 d}$ & $f=\frac{v}{\lambda}$ \\
Frequency shift & $\Delta f=-\frac{2 f_{0}^{2} \Delta m}{A \sqrt{\rho \mu}}$ & $\Delta f=-C_{m} f_{o}^{2} h^{\prime} \Delta m$ \\
Sensitivity & $S=\frac{\Delta f}{\Delta m}$ & \\
\hline
\end{tabular}

mass variations $[44,45]$. Hence the shift of the resonance frequency will be observed due to the mass variations [43,44].

SAW sensor works slightly different from QCM sensor in terms of the propagation of the acoustic wave. The acoustic wave for SAW sensor propagates on the surface of the substrate instead. When an input radio frequency voltage is applied across the interdigitated transmitter (IDT), it induces deformations in the piezoelectric substrate and give rise to a Rayleigh surface wave confined within one acoustic wavelength on the surface [46]. As the wave transverses the gap between two arrays of the IDTs and it reaches the receiver IDTs, the mechanical energy is converted back into radiofrequency as an output [45]. As there is a change in mass arising from a coating or when vapour is adsorbed on the surface, it yields in a frequency shift and allows the application in monitoring of vapour. Fig. 4(b) shows the sensing mechanism of SAW sensor towards analyte gas.

These parameters play an important role in analysing the frequency shifts; (i) resonant frequency, (ii) frequency shift using the Sauerbery's equation and (iii) sensitivity. QCM and SAW sensor both have different equations involved in providing the three key parameters. Hence, the key parameters are summarised in Table 2 where; $f$ is the resonant frequency, $v$ is the velocity of acoustic wave, $\lambda$ is the wavelength between IDT, $d$ is the thickness of crystal, $\Delta f$ is the frequency shift, $C_{m}$ is the mass sensitivity coefficient, $h$ ' is the thickness of sensitive layer, $\Delta m$ is the change of mass density, $f_{o}$ is the unperturbed frequency of oscillation, $A$ is the active area of crystal, $\rho$ is the density, $\mu$ is the shear modulus of quartz, and $\Delta m$ is the change of mass density.

\section{Vapour sensing material for acoustic wave sensors}

The materials used as the sensing layer play a crucial role in defining the performance of the sensor towards the detection purpose. The importance of a sensing layer is to enhance the sensing mechanism. It is deposited onto the sensor via various methods such as drop casting [47-49], electrospinning [50-52], self-assemble monolayer [53-55], and sputtering [56-58].

Some of the commonly used sensing layers are oxide [24,58-63], carbon nanotubes [48,64-69], polymer [62,70,71] and metalorganic framework [49,72,73]. Metal oxide is known to have high thermal stability and sensitivity while carbon-based material has good mechanical and chemical stability aside from providing a large surface area. Besides, polymers offer high permeability and fast response. Polymer upholds the sorption - desorption phenomena in gas detection whereby these phenomenon are greatly influenced by the thickness and the physicochemical properties of the sensing layer such as the molecular mass and affinity [74]. The molecules of the analyte gas are adsorbed on to the sensor due to the presence of chemical interactions between the gas molecules and the surface of the sensing layer. Meanwhile, the desorption process needs to take into consideration of the binding energy of the analyte gas molecules and the sensing layer [25]. This work highlights the use of polymer in detecting VOCs. Recently, the use of biopolymer has called the attention of many researchers. Biopolymers are known for their biodegradable properties, hydrophilicity and ability to be functionalized in accordance to the analytes to be adsorbed. The following section also emphasises previous work on chitosan and pegylated lipopolymer as sensing materials. Fig. 5 summarises the types of sensing layer on acoustic wave gas sensor.

\subsection{Metal oxides}

Oxides are commonly co-existing with metals. The presence of at least one oxygen atom in a metal compound is called metal oxide. Metal oxide is known to be a selective sensing material. In brief, metal oxides undergo chemical and electronic sensitization to detect analyte molecules [51].

Zinc oxide $(\mathrm{ZnO})$ is among the metal oxide that most often used for gas sensing purposes [63,75]. Fig. 6 shows the FESEM images of $\mathrm{ZnO}$ nanostructure grains [63]. The sensing of an analyte using oxide involves the oxidation reaction between the analyte gas and the sensing material. A study by Horrillo et al., focuses on the use of ZnO film fabricated onto the $99.50 \mathrm{MHz}$ ST-cut SAW device in detecting nitrogen dioxide $\left(\mathrm{NO}_{2}\right)$. The experimental work has been done on various gas analytes at concentrations ranging from 400 $\mathrm{ppb}$ to $16 \mathrm{ppm}$. The measurement results depicted $\mathrm{NO}_{2}$ at concentration 16 ppm gives the highest frequency shift [58]. The selectivity towards $\mathrm{NO}_{2}$, hydrogen, methane, carbon monoxide and acetone were tested separately [58]. The results proved that the ZnO layer was behaving selectively towards $\mathrm{NO}_{2}$ according to the frequency shift observed for the gases tested. The frequency shift for $\mathrm{NO}_{2}$ at $16 \mathrm{ppm}$ is approximately $275 \mathrm{kHz}$ as compared to hydrogen, methane, carbon monoxide and acetone were all with below 50 $\mathrm{kHz}$ shifts [58]. This work concluded that the use of metal oxide has the potential to be a selective sensing material.

Metal oxide has the advantage in terms of having different shapes in nanoscale. This includes the nanorods and colloid spheres [76]. Fig. 7 shows the illustration of adsorption on $\mathrm{ZnO}$ colloid spheres. Aside from $\mathrm{ZnO}$, Tin dioxide $\left(\mathrm{SnO}_{2}\right)$, silicon dioxide $\left(\mathrm{SiO}_{2}\right)$ and titanium dioxide $\left(\mathrm{TiO}_{2}\right)$ are some other frequently used materials for sensing purposes including VOCs sensing [54,77-81]. Xie et al. and Zhu et al., both used QCM to detect humidity using ZnO colloid spheres and mesoporous $\mathrm{SnO}_{2}-\mathrm{SiO}_{2}$, respectively. At $75 \%$ relative humidity (RH), mesoporous $\mathrm{SnO}_{2}-\mathrm{SiO}_{2}$ attained a shorter response time of $14 \mathrm{~s}$ as to $167.7 \mathrm{~s}$ for $\mathrm{ZnO}$ colloid spheres. This 


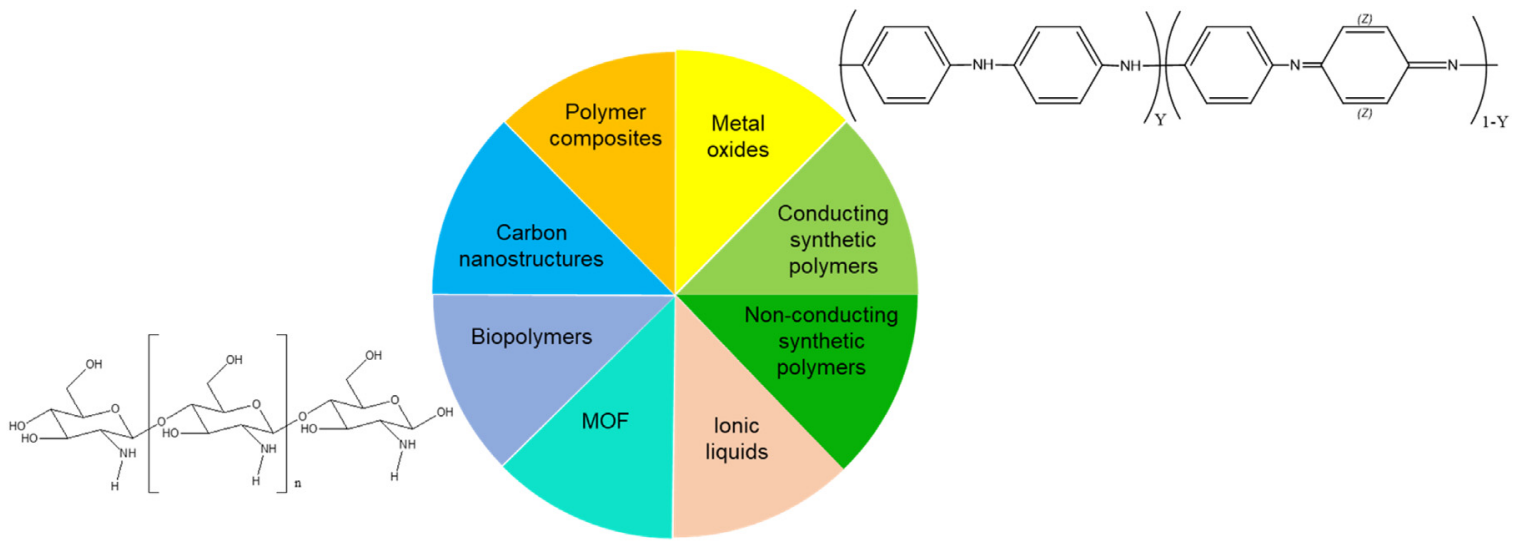

Fig. 5. Different type of sensing layer coated on acoustic wave gas sensors [45].

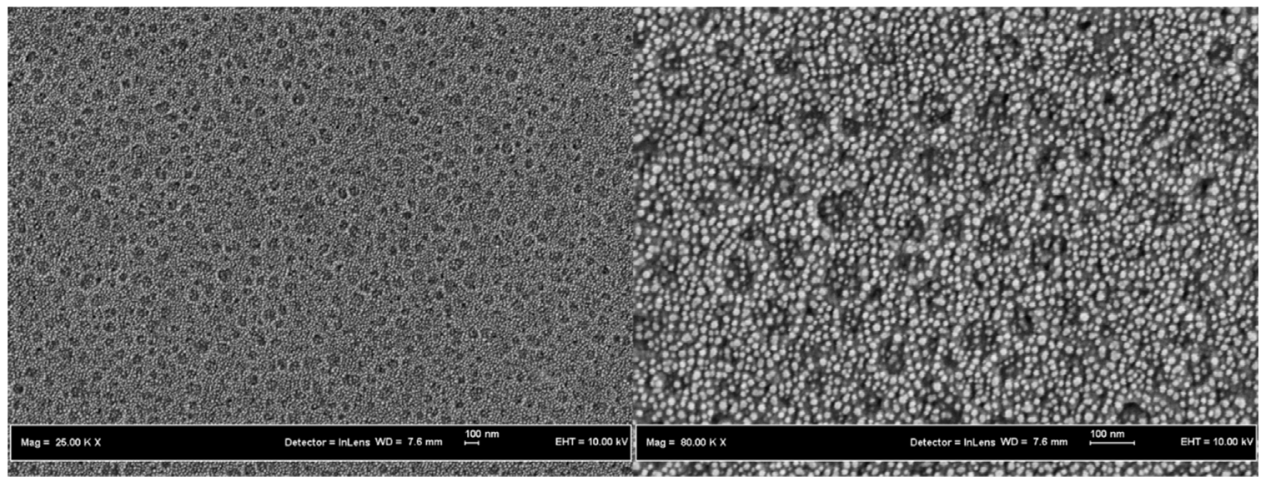

(a)

(b)

Fig. 6. The FESEM images of the $\mathrm{ZnO}$ nanostructure grains under magnification (a) $\mathrm{x} 25 \mathrm{k}$ and (b) $\mathrm{x} 80 \mathrm{k}$.

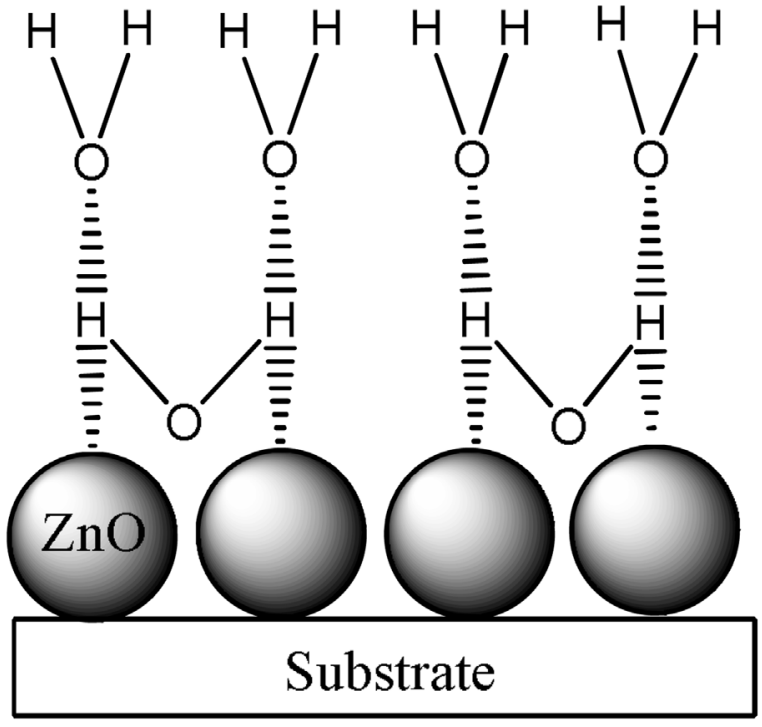

Fig. 7. Representation of adsorption model of water vapour on $\mathrm{ZnO}$ colloid speheres [76].

alludes to the existence of an ample amount of mesopores that has allowed the actions of forces of Van Der Waals and weak hydrogen bond between the water vapour molecules to $\mathrm{SiO}_{2}$ compound. Besides, the addition of a semiconductor $\mathrm{SnO}_{2}$ promotes the acceleration of response rate [79].

Apart from metals, semi-conducting metal graphene is also known as a quasi-metal that has been experimented as a sens- ing material. Sayago et al., has conducted a study on modifying graphene into graphene oxide in the application of any sensor. The study highlighted the formation of hydrogen bonding between graphene oxide and analyte gas which implies good sensitivity for sensor application [66]. In [66], graphene oxide was used to detect dichloroethane (DCE), dimethylacetamide (DMA), dimethyl methyl phosphonate (DMMP), and dipropylene glycol ether (DPGME) with a limit of detection $33.3 \mathrm{ppm}, 4.34 \mathrm{ppm}, 0.0097 \mathrm{ppm}$, and $0.039 \mathrm{ppm}$ respectively. Thus, graphene oxide promoted the highest sensitivity towards DMMP detection at $3067 \mathrm{~Hz} / \mathrm{ppm}$. Despite the ability of oxides in improving sensor selectivity, it requires a relatively high working temperature to achieve a good response. The oxidation reaction puts the use of oxides at the disadvantage of being non-reproducible. Hence, oxide alone on a sensor requires further enhancements. Related works are summarised in Table 3.

\subsection{Synthetic polymers}

Polymer coatings provide a chemical interface for vapour sensing via sorption of the analytes [74]. The chemical interface is influenced by several factors including thickness of the polymer film and the physicochemical properties of the polymer to the analytes vapour; (i) affinity and (ii) molecular mass [74]. A study by Yadava et al., underlined that the activation energies are associated with the surface site, specifically for the gaseous adsorption and desorption on the solid surfaces [25]. Sorption and desorption phenomena occurring on the surface of the solid eventually create a sensitive area where the diffusion of the vapour molecules in and out of the polymer overlays and causes fluctuation in vapour loading due to the Brownian motion [25]. Fig. 8 illustrates the 
Table 3

Summary of the previous work on oxides based coated sensors in detecting VOCs.

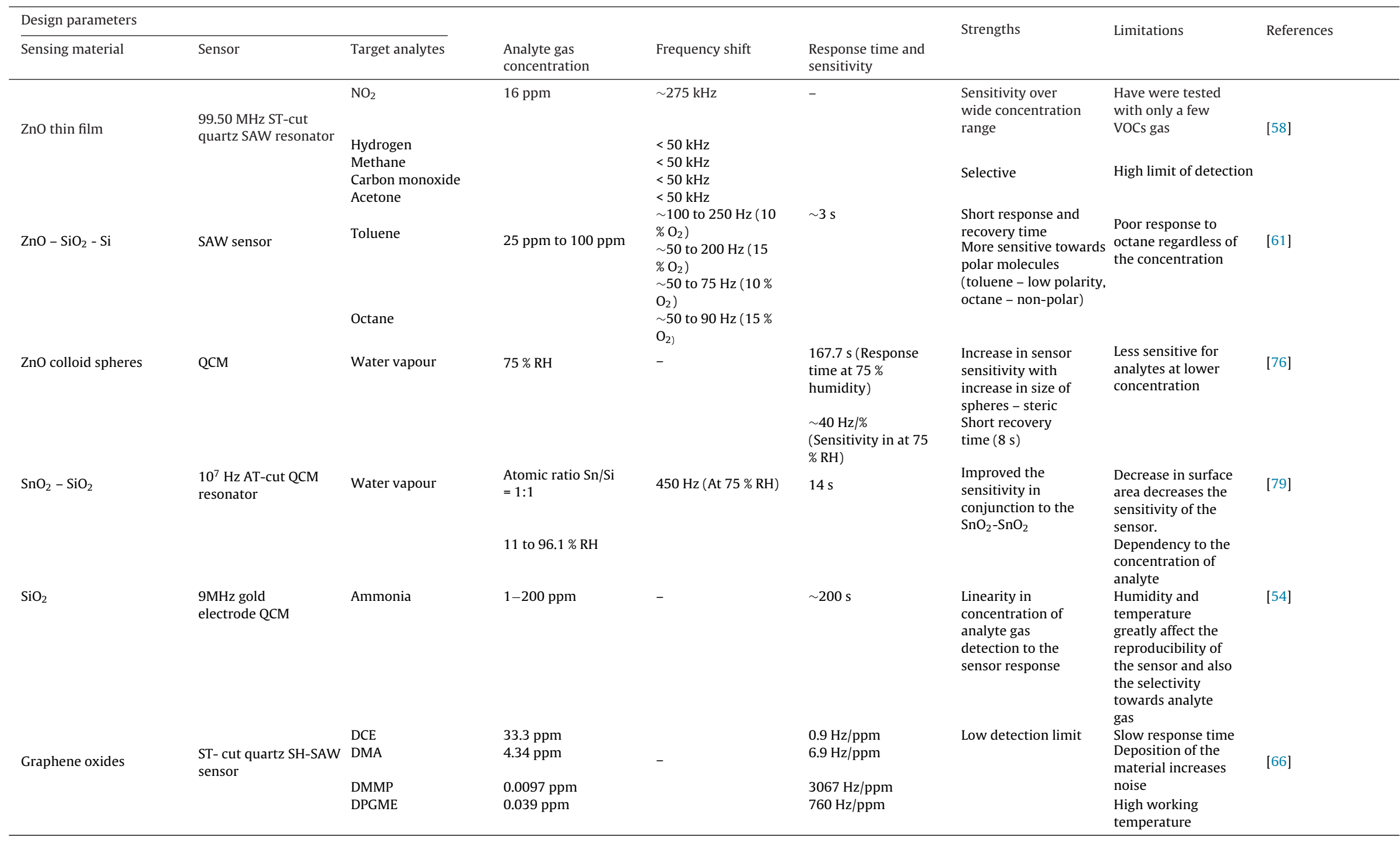




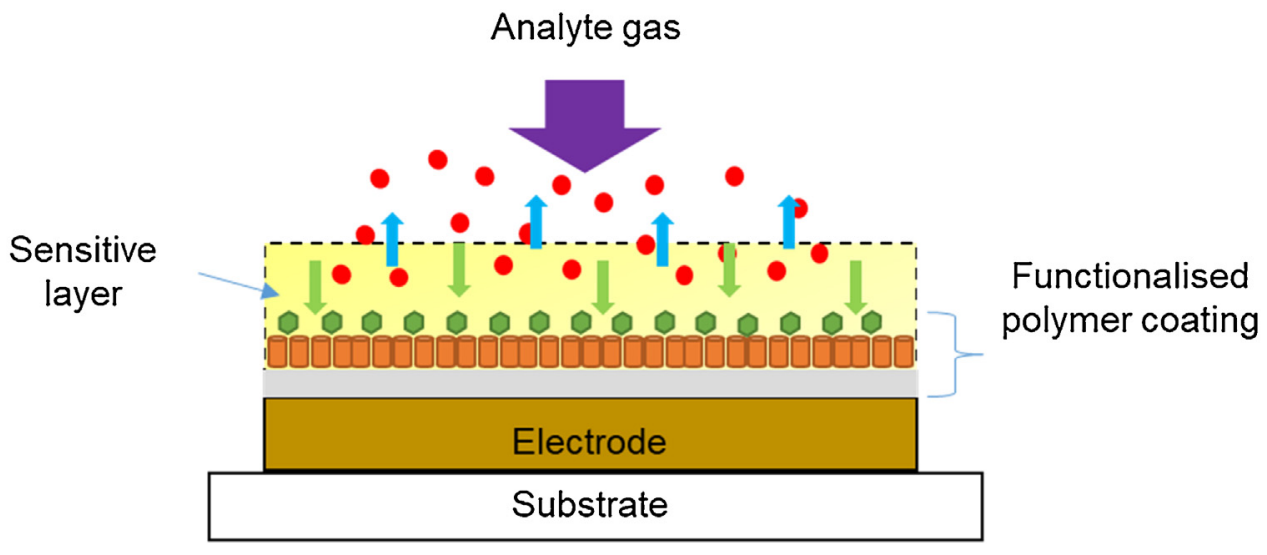

Fig. 8. Sorption-desorption phenomena on polymer coated sensor [25].

sorption-desorption phenomena. The rate of sorption on the surface of the solid is defined as the rate for the vapour molecules to stick or imprinting adhesive behaviour. The rate of desorption depends on the concentration and binding energy of the vapour molecules to the polymer film surface [25]. The study deduced that the polymers selected as the coating for SAW sensor coating must have weak chemical interactions with the analyte molecules for the sensor to operate reversibly [25].

Another study by Afzal et al., investigated the detection of different organic vapours on a coated SAW sensor with different polymers [46]. In addition, the authors examined the effect of the sensing film thickness on the sensing response. The difference in the functional groups of the vapours allowed the sensing response to be more selective. However, further investigation on the properties of the film and the analytes behaviours are required. More studies on VOCs detection have illustrated the capability of synthetic polymers in detecting VOCs [46,56,70,82-87].

Molecularly imprinted polymer (MIP) is also a commonly used method in the deposition of the sensing layer. Some materials such as a mixture of hexanal and $(1: 1, \mathrm{v} / \mathrm{v})$ mixture of methanol and acetonitrile mixture uphold the ability to form into MIPs according to the properties of the substance [88]. The functionalisation of the MIP layer may provide an innovative path to synthesis a sensing layer with selectivity towards different gases. Experimental work has been done in detecting gas from ketone and ether group using hydrophobic MIP as the sensing layer on a QCM device alongside a few other gases [88]. From the results obtained, the hydrophobic MIP templated with hexanal sensing layer enhances the QCM device sensitivity at $3.11 \mathrm{~Hz} / \mathrm{ppm}$ towards hexanal at 80 $\%$ RH more than other gases tested. Another experimental work by Bhattacharyya Banerjee et al., particularly focused on the detection of benzene and aromatic compounds [89]. The limit of detection attained for benzene, toluene and xylene were $0.98 \mathrm{ppm}$, $1.25 \mathrm{ppm}$ and $1.42 \mathrm{ppm}$ respectively. The results demonstrated that MIP was more sensitive towards aromatic compounds it has been templated to as benzene achieved the greatest sensitivity at $2.605 \mathrm{~Hz} / \mathrm{ppm}$. The aromatic compound was templated with 1,2,3trimethoxybenzene which explains the selectivity from the use of nonanal gas detection in MIP synthesis previously [88]. The templated MIPs materials make the MIPs more selective and sensitive towards the analyte gas of the same functional group.

Aside from MIP, conducting polymer has a good potential in VOCs sensing application. Several research works have been done on polyaniline (PANI), both its emeraldine salt (ES) and emeraldine base (EB) $[44,90]$. Both works emphasised the use of $5 \mathrm{MHz}$ QCM in detecting $5 \mathrm{ppm}$ alcohol. Ayad and Torad claimed that thicker film promotes greater chance for hydrogen bonds with EB and thus, increase the sensitivity of the sensor. The study was extended to the use of protonated PANI (ES) thin film [90]. The extended study on PANI (ES) thin film illustrates the improvement in sensing towards the alcohols. The sensitivity of ethanol rises from $2.501 \mathrm{~Hz} / \mathrm{ppm}$ to $20.7 \mathrm{~Hz} / \mathrm{ppm}$. It can be concluded from the study that protonated PANI film gives higher response and sensitivity towards the analyte [90]. The presence of $\mathrm{H}^{+}$ions in the protonated film allows greater molecules interaction. Related works on synthetic polymer-based sensor are summarised in Table 4.

\subsection{Biopolymers}

In the recent development, the use of biopolymer has attracted the attention of many researchers. Biopolymers are known for its biodegradable properties and its ability to be functionalised in accordance to the analytes to be adsorbed. Biopolymers are polymers made of biomolecules that are bonded covalently and obtained from natural sources such as carbohydrates, proteins and fats. Biopolymers are more complex than synthetic polymers in terms of structure and shape which are important for their particular functions [91]. The following section underlines the work on chitosan, cellulose and pegylated lipopolymer as sensing materials.

\subsubsection{Chitosan based sensor}

Chitosan is a naturally occurring polysaccharides polymer from various sources. There are two reactive paths for chitosan, which are via reaction with free amino groups and the hydroxyl group [57,92-94]. Chitosan is obtained from the deacetylation of chitin [57,95-103]. Fig. 9 represents the structural formula of chitosan. The advantage of using chitosan in the fabrication of thin film includes good mechanical strength, low cost, hydrophilicity and hydrophobicity $[47,104,105]$ and being biodegradable [106-108]. The existence of piezoelectricity behaviour in chitosan marks good potential in using it as a sensing material on a piezoelectric sensor device [109].

Triyana et al., and Ayad et al. both utilised the chitosan as the sensing layer for volatile gases $[47,111,112]$. Ayad et al. have stepped up their work by incorporating PANI in the chitosan-based sensing layer to detect amines. Both researchers experimented the detection of alcohol using a QCM sensor. Chitosan-based sensing layer used by Triyana et al., showed a lower sensitivity of ethanol 0.4 $\mathrm{Hz} / \mathrm{mgL}^{-1}$ [112] than the ethanol detection in [47] which is at 19.35 $\mathrm{Hz} / \mathrm{mgL}^{-1}$. This may be due to the presence of a self-assembled monolayer L-cysteine and a crosslinking agent that is glutaraldehyde to immobilised chitosan onto the QCM substrate [112] and the difference in measurement setup in which the resonance frequency of the QCM is altered. Chitosan has the tendency to attach and the capacity to be more adhesive with the presence of the selfassembled substance and the crosslinking agent that allows the 
Table 4

Summary of the previous work on synthetic polymer coated sensors in detecting VOCs.

\begin{tabular}{|c|c|c|c|c|c|c|c|c|}
\hline \multicolumn{3}{|l|}{ Design parameters } & \multirow[b]{2}{*}{$\begin{array}{l}\text { Analyte gas } \\
\text { concentration }\end{array}$} & \multirow[b]{2}{*}{ Frequency shift } & \multirow[b]{2}{*}{$\begin{array}{l}\text { Response time and } \\
\text { sensitivity }\end{array}$} & \multirow[t]{2}{*}{ Strengths } & \multirow[t]{2}{*}{ Limitations } & \multirow[t]{2}{*}{ References } \\
\hline Sensing material & Sensor & Target analytes & & & & & & \\
\hline $\begin{array}{l}\text { Poly-vinylphenol } \\
\text { (PVP), polystyrene (PS) } \\
\text { and ethyl carbamate } \\
\text { (EC) }\end{array}$ & $\begin{array}{l}433 \mathrm{MHz} \text { ST-quartz } \\
\text { SAW }\end{array}$ & $\begin{array}{l}\text { Propylene, ether, } \\
\text { butanone, } \\
\text { methylbenzene }\end{array}$ & - & $200 \mathrm{kHz}$ & $\sim 150 \mathrm{~s}$ & $\begin{array}{l}\text { Use of array in } \\
\text { detecting flammable } \\
\text { vapours }\end{array}$ & $\begin{array}{l}\text { Focuses only on } \\
\text { aromatic compounds } \\
\text { High resonance } \\
\text { frequency }\end{array}$ & [46] \\
\hline Polyepichlorhydrine (PECH) & $\begin{array}{l}\text { ST-X cut quartz SAW } \\
\text { delav line }\end{array}$ & & $1.25 \mathrm{mg} / \mathrm{mL}(\mathrm{PECH})$ & $200 \mathrm{kHz}$ & & & $\begin{array}{l}\text { The experiment was } \\
\text { conducted at high }\end{array}$ & \\
\hline Poly etheruretane (PEUT) & & Alcohol & $2.5 \mathrm{mg} / \mathrm{mL}$ (PEUT) & $300 \mathrm{kHz}$ & $2 \min$ & $\begin{array}{l}\text { High sensitivity in } \\
\text { detecting alcohol }\end{array}$ & $\begin{array}{l}\text { conducted at high } \\
\text { concentration of }\end{array}$ & [56] \\
\hline Polybutadiene (PBD) & & & $10 \mathrm{mg} / \mathrm{mL}$ (PDMS) & $400 \mathrm{kHz}$ & & & alcohol only & \\
\hline Poly dimethylsiloxane (PDMS) & & & 5 mg/mL (PBD) & $500 \mathrm{kHz}$ & & & & \\
\hline $\begin{array}{l}\text { Poly(butyl } \\
\text { methacrylate) PBMA }\end{array}$ & $433 \mathrm{MHz}$ STW & Octane & $\begin{array}{l}11.5 \mathrm{ppmv} \\
22.9 \mathrm{ppmv} \\
34.4 \mathrm{ppmv}\end{array}$ & $\begin{array}{l}40 \mathrm{kHz} \\
70 \mathrm{kHz} \\
\sim 100 \mathrm{kHz}\end{array}$ & & & & \\
\hline $\mathrm{PECH}$ & & & $2.3 \mathrm{ppmv}$ & $3 \mathrm{kHz}$ & & & Specifically built for & \\
\hline $\begin{array}{l}\text { Poly(cholorotrifluoro } \\
\text { ethylene-co-vinylidene }\end{array}$ & & Chloroform & & & $3 \mathrm{~min}$ & Less coating effort & long term & [82] \\
\hline $\begin{array}{l}\text { ethylene-co-vinylidene } \\
\text { (PCFV) }\end{array}$ & & & $\begin{array}{l}6.9 \mathrm{ppmv} \\
11.6 \mathrm{ppmv}\end{array}$ & $\begin{array}{l}11 \mathrm{kHz} \\
17.5 \mathrm{kHz}\end{array}$ & & & measurement only & \\
\hline L-grease & & & $0.8 \mathrm{ppmv}$ & $8 \mathrm{kHz}$ & & & & \\
\hline PDMS & & Xylene & $1.5 \mathrm{ppmv}$ & $19.5 \mathrm{kHz}$ & & & & \\
\hline Polyisobutylene (PIB) & & & $4.5 \mathrm{ppmv}$ & $\begin{array}{l}50 \mathrm{kHz} \text { (all shifts } \\
\text { were analysed } \\
\text { based on PBMA) }\end{array}$ & & & & \\
\hline $\begin{array}{l}\text { Polymethyl[3-(2- } \\
\text { hydroxy)phenyl] } \\
\text { siloxane (PMPS) }\end{array}$ & $\begin{array}{l}\text { Single-port SAW } \\
\text { resonator }\end{array}$ & $\begin{array}{l}\text { Dimethyl } \\
\text { methylphosphonate } \\
\text { (DMMP) }\end{array}$ & $5-40 \mathrm{ppm}$ & $35-130 \mathrm{kHz}$ & $\begin{array}{l}30 \mathrm{~s} \text { (response } \\
\text { time) } \\
3 \mathrm{kHz} / \mathrm{ppm} \\
\text { (sensitivity) }\end{array}$ & $\begin{array}{l}\text { Fast response and } \\
\text { reproducibility } \\
\text { Low limit of detection }\end{array}$ & $\begin{array}{l}\text { DMMP is not listed as } \\
\text { one of the lung cancer } \\
\text { biomarkers }\end{array}$ & [70] \\
\hline PECH & ST-X cut Quartz SAW & Alcohol & - & $260 \mathrm{kHz}(\mathrm{PECH})$ & $10 \mathrm{~min}$ & $\begin{array}{l}\text { Present the ability of } \\
\text { PEUT for great sensor } \\
\text { response with a }\end{array}$ & $\begin{array}{l}\text { Not as sensitive as } \\
\text { towards octane and } \\
\text { toluene when using }\end{array}$ & [83] \\
\hline $\begin{array}{l}\text { PEUT } \\
\text { PDMS }\end{array}$ & sensor & & & $\begin{array}{l}500 \mathrm{kHz} \text { (PEUT) } \\
200 \mathrm{kHz} \text { (PDMS) }\end{array}$ & & $\begin{array}{l}\text { thickness at } 150 \mathrm{~nm} \\
\text { coating }\end{array}$ & PDMS & \\
\hline PIB & SAW sensor array & $\begin{array}{l}\text { Styrene, isoprene, } \\
\text { hexanal, } \\
\text { 1,2,4-trimethyl } \\
\text { benzene, heptanal, } \\
\text { benzene }\end{array}$ & - & - & - & $\begin{array}{l}\text { Simple cleansing } \\
\text { process using nitrogen } \\
\text { carrier gas }\end{array}$ & $\begin{array}{l}\text { Spin-coat method } \\
\text { made the thickness of } \\
\text { film challenging to } \\
\text { control }\end{array}$ & [84] \\
\hline PEUT, PDMS & $\begin{array}{l}118 \mathrm{MHz} \text { AT- cut quartz } \\
\text { love wave device }\end{array}$ & $\begin{array}{l}\text { Water vapour } \\
\text { (humidity) }\end{array}$ & - & - & - & $\begin{array}{l}\text { Implementation of } \\
\text { automatic spraying } \\
\text { system in controlling } \\
\text { the deposition of } \\
\text { polymeric layer }\end{array}$ & $\begin{array}{l}\text { PEUT is less sensitive } \\
\text { towards hydroxyl } \\
\text { group as compared to } \\
\text { PDMS }\end{array}$ & [85] \\
\hline PIB & $\begin{array}{l}\text { SAW delay line } \\
\text { oscillator }\end{array}$ & $\begin{array}{l}\text { Chloroform, } \\
\text { chlorobenzene, o- } \\
\text { Dichlorobenzene, } \\
\text { n-heptane, toluene, } \\
\text { n-Hexane and } \\
\text { n-Octane }\end{array}$ & $1 \mathrm{ppm}$ & - & $30 \mathrm{~s}$ & $\begin{array}{l}\text { Multiple thickness of } \\
\text { single polymer with } \\
\text { potential in enhancing } \\
\text { sensor performance }\end{array}$ & $\begin{array}{l}\text { Challenging in } \\
\text { classifying the analyte } \\
\text { gas detected }\end{array}$ & [86] \\
\hline
\end{tabular}


Table 4 (Continued)

\begin{tabular}{|c|c|c|c|c|c|c|c|c|}
\hline \multicolumn{3}{|l|}{ Design parameters } & \multirow[b]{2}{*}{$\begin{array}{l}\text { Analyte gas } \\
\text { concentration }\end{array}$} & \multirow[b]{2}{*}{ Frequency shift } & \multirow[b]{2}{*}{$\begin{array}{l}\text { Response time and } \\
\text { sensitivity }\end{array}$} & \multirow[t]{2}{*}{ Strengths } & \multirow{2}{*}{ Limitations } & \multirow{2}{*}{ References } \\
\hline Sensing material & Sensor & Target analytes & & & & & & \\
\hline \multirow[t]{2}{*}{ PS } & 9MHz AT-cut QCM & $\begin{array}{l}\text { Toluene } \\
\text { n-octane } \\
\text { acetone }\end{array}$ & & $\begin{array}{l}\text { PS; } \\
60.0 \mathrm{~Hz} \\
18.0 \mathrm{~Hz}\end{array}$ & 20 s (response time) & & & \\
\hline & & & $1000 \mathrm{ppm}$ & $\begin{array}{l}6.2 \mathrm{~Hz} \\
3.1 \mathrm{~Hz} \\
\text { PBD; }\end{array}$ & & $\begin{array}{l}\text { Demonstrating the } \\
\text { selectivity of analyte } \\
\text { gases towards different }\end{array}$ & $\begin{array}{l}\text { Works best at low } \\
\text { temperature - lower }\end{array}$ & [87] \\
\hline \multirow{4}{*}{ PBD } & & ethanol & & $69 \mathrm{~Hz}$ & $\sim 0.095 \mathrm{~Hz} / \mathrm{ppm}$ & polymer coatings & & \\
\hline & & & & $\begin{array}{l}12 \mathrm{~Hz} \\
2.2 \mathrm{~Hz}\end{array}$ & (sensitivity - PBD) & & & \\
\hline & & & & $2.9 \mathrm{~Hz}$ & & & & \\
\hline & & Hexanal & & $89.89 \mathrm{~Hz}$ & $42 \mathrm{~s}(80 \% \mathrm{RH})$ & $\begin{array}{l}\text { Improve selectivity } \\
\text { towards VOCs at high } \\
\text { humidity }\end{array}$ & & \\
\hline \multirow[t]{7}{*}{ Hydrophobic MIP } & $\begin{array}{l}\text { AT-cut } 8.98 \pm 30 \mathrm{k} \mathrm{MHz} \\
\text { QCM gold electrode }\end{array}$ & Octanal & 25 ppm (LOD; 2 ppm) & $\begin{array}{l}<20 \mathrm{~Hz} \\
<20 \mathrm{~Hz}\end{array}$ & & & $\begin{array}{l}\text { Low detection range in } \\
\text { concentration }\end{array}$ & [88] \\
\hline & & $\begin{array}{l}\text { TMA } \\
\mathrm{NH}_{3}\end{array}$ & & $\begin{array}{l}<20 \mathrm{~Hz} \\
<20 \mathrm{~Hz}\end{array}$ & & Encountered the & & \\
\hline & & Ethanol & & $<20 \mathrm{~Hz}$ & $3.11 \mathrm{~Hz} / \mathrm{ppm}$ & sensitivity of QCM & & \\
\hline & & Acetone & & $<20 \mathrm{~Hz}$ & & towards numiaity & & \\
\hline & & Acetic acid & & $<20 \mathrm{~Hz}$ & & & & \\
\hline & & Diethyl ether & & $<20 \mathrm{~Hz}$ & & & & \\
\hline & & $\begin{array}{l}\text { Benzene } \\
\text { Toluene }\end{array}$ & $\begin{array}{l}0.98 \mathrm{ppm} \\
1.25 \mathrm{ppm}\end{array}$ & & $\begin{array}{l}2.605 \mathrm{~Hz} / \mathrm{ppm} \\
2.147 \mathrm{~Hz} / \mathrm{ppm}\end{array}$ & Low detection limit & Favours to adsorption & [89] \\
\hline \multirow[t]{3}{*}{ MIP (Drop coating) } & $10 \mathrm{MHz}$ AT-cut QCM & o-xylene & $1.42 \mathrm{ppm}$ & - & $1.695 \mathrm{~Hz} / \mathrm{ppm}$ & $(0.98 \mathrm{ppm})$ & of benzene & \\
\hline & & m-xylene & $1.42 \mathrm{ppm}$ & & $1.993 \mathrm{~Hz} / \mathrm{ppm}$ & & Sensor response & \\
\hline & & $\begin{array}{l}\text { p-xylene } \\
\text { Ethanol }\end{array}$ & 1.36 ppm & $\sim 60 \mathrm{~Hz}$ & $1.645 \mathrm{~Hz} / \mathrm{ppm}$ & & $\begin{array}{l}\text { depicted above } 400 \\
\text { ppm }\end{array}$ & \\
\hline $\begin{array}{l}\text { PANI emeraldine base } \\
\text { (EB) thin film }\end{array}$ & $\begin{array}{l}5 \mathrm{MHz} \text { QCM resonator } \\
\text { AT-cut quartz }\end{array}$ & $\begin{array}{l}\text { Methanol } \\
\text { 1-propanol } \\
\text { 2-propanol }\end{array}$ & $5 \mathrm{ppm}$ & $\begin{array}{l}\sim 40 \mathrm{~Hz} \\
\sim 100 \mathrm{~Hz} \\
\sim 80 \mathrm{~Hz}\end{array}$ & $\begin{array}{l}2.501 \mathrm{~Hz} / \mathrm{ppm} \\
\text { (ethanol) }\end{array}$ & $\begin{array}{l}\text { Low limit of detection } \\
(2 \mathrm{ppm})\end{array}$ & $\begin{array}{l}\text { Focuses only on alcohol } \\
\text { detection }\end{array}$ & [90] \\
\hline $\begin{array}{l}\text { PANI emeraldine salt } \\
\text { (ES) thin }\end{array}$ & $\begin{array}{l}5 \mathrm{MHz} \text { QCM AT-cut } \\
\text { quartz }\end{array}$ & $\begin{array}{l}\text { Ethanol } \\
\text { Methanol } \\
\text { 1-propanol } \\
\text { 2-propanol }\end{array}$ & $\begin{array}{l}5 \mathrm{mgL}^{-1}(120 \mathrm{~nm} \text { film } \\
\text { thickness) }\end{array}$ & $\begin{array}{l}\sim 80 \mathrm{~Hz} \\
\sim 120 \mathrm{~Hz} \\
\sim 65 \mathrm{~Hz} \\
\sim 50 \mathrm{~Hz}\end{array}$ & $\begin{array}{l}20.7 \mathrm{~Hz} / \mathrm{mgL}^{-1} \\
25.344 \mathrm{~Hz} / \mathrm{mgL}^{-1}\end{array}$ & $\begin{array}{l}\text { Enhances the } \\
\text { sensitivity as to the } \\
\text { results attained by EB }\end{array}$ & $\begin{array}{l}\text { Focuses only on alcohol } \\
\text { detection }\end{array}$ & [44] \\
\hline
\end{tabular}




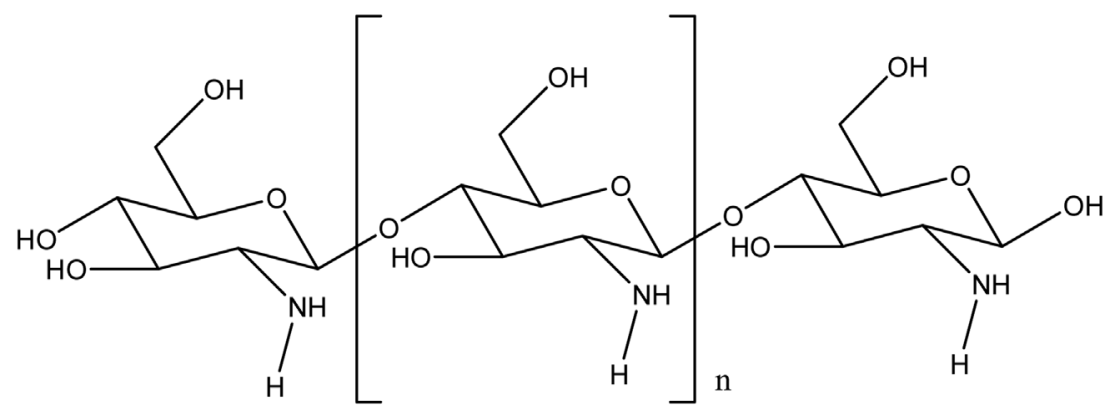

Fig. 9. Chitosan structural formula [110].

adsorption to occur covalently [112]. However, other factors such as the thickness of the coatings, and the preparation of the sensing material may also contribute to the alteration of results obtained. Besides, the fabrication method is one of the essential matters that need to be investigated thoroughly. Further studies on the bonds between the sensing film and the analyte gas are highly essential as the presence of hydroxyl groups and free amino group in chitosan determines the efficiency of analyte gas adsorption. This eventually shows that chitosan has potential in being highly selective to certain gas detection. Further improvements need to be done in functionalisation of chitosan.

\subsubsection{Lipopolymer based sensor}

Aside from chitosan, lipopolymer is another form of biopolymer that potentially can be used as a sensing layer [113]. Pegylated lipopolymer is derived from lipid derivatives and polyethylene, therefore it is claimed to be able to enhance the stability of lipopolymer [113]. Rahman, Ma'Radzi and Zakaria experimented VOCs of different groups with various lipopolymers such as 1,2-distearoyl-sn-glycero-3-phosphoethanolamine (lipid) lipopolymer, 1,2-distearoyl-sn-glycero-3-phosphoethanolamine$\mathrm{N}$-[succinyl(polyethylene glycol) 2000] (succinyl) lipopolymer and 1,2-distearoyl-sn-glycero-3-phosphoethanolamine-N-[carboxy (polyethylene glycol) 2000] (carboxyl) lipopolymer [113]. The results obtained showed that the hexanal gas gives the highest frequency shifts to all the pegylated lipopolymers [113] where the frequency shift obtained is the highest on QCM coated with succinyl lipopolymer that is $69 \mathrm{~Hz}$, followed by carboxyl lipopolymer at $35 \mathrm{~Hz}$ and lipid lipopolymer at $19 \mathrm{~Hz}$. The uncoated sensors give the least shift in frequency for all analyte gases tested. It can be concluded from the experiment that due to the different physicochemical properties of each gases interacting to the sensing materials, the different groups of analyte gases were selective towards a different type of lipopolymer $[113,114]$. More detailed research on the interaction of the functional groups in the sensing materials and the analytes should be done to re-evaluate the selectivity of the sensor. The results obtained from Rahman et al., was challenging to be interpreted in concluding which material was selective in detecting different types of analytes [114]. Related works on the biopolymer-based sensor are summarised in Table 5.

\subsection{Carbon nanotubes (CNTs)}

CNT has contributed to gas sensing application for years. CNT is a promising carbon-based material in providing alteration to the physicochemical properties for sensors. This is due to its unique properties in having a large surface area with high electron mobility and excellent chemical reactivity [115]. These properties made CNTs an ideal alternative sensing layer to enhance vapour adsorption processes.

CNT is commonly found in two chiral structures, (i) singlewalled CNT (SWCNT) and (ii) multi-walled CNT (MWCNT)
$[45,116,117]$. SWCNTs is made up of a sheet of carbon atoms or graphene rolled up into the cylindrical structure and crosslinking several SWCNT yields in MWCNT formation. The basic principle of the sorption of analyte gas using CNT is that the molecules of the analyte gas adsorbed onto the wall of CNT will eventually change the properties. This change is signalling that the detection is happening as there is a change in conductivity. CNT has greater surface areas for contact and its ability to detect the change in electrical properties rather than just change in mass improves the sensitivity of a sensor [64]. However, CNT tends to only improve the sensitivity of a sensor but not the selectivity. The improvement CNT brought to the sensing responses can be found in Fig. 10 [116]. Several works on the use of SWCNTs and MWCNTs on a SAW and QCM sensor have been done for VOCs detection [118-122]. Penza et al. have developed SWCNTs and MWCNTs coated $433.92 \mathrm{MHz}$ SAW sensor in the detection of ethanol, ethyl acetate and toluene exposed to the concentration of $85 \mathrm{ppm}, 178 \mathrm{ppm}$, and $93 \mathrm{ppm}$ correspondingly. From both SWCNTs and MWCNTs dispersed into ethanol, ethanol gives the lowest limit of detection LOD at $1.3 \mathrm{ppm}$ and $1.4 \mathrm{ppm}$. This trend is similarly observed as to when SWCNTs and MWCNTs were dispersed on toluene, resulted in greater absolute sensitivity 37.35 $\mathrm{Hz} / \mathrm{ppm} / \mathrm{kHz}$ followed by ethanol detection $31.70 \mathrm{~Hz} / \mathrm{ppm} / \mathrm{kHz}$ and ethyl acetate $27.25 \mathrm{~Hz} / \mathrm{ppm} / \mathrm{kHz}[118,119]$.

Sayago et al. also investigated the use of CNTs on a SAW sensor to detect octane and toluene exposed at $25 \mathrm{ppm}$ concentration [123]. They claimed that the adsorption mechanism adhered to the physisorption phenomena where Van der Waals interaction takes place. The author tested the selectivity of analytes towards the sensing layer by exposing the sensor to $\mathrm{NO}_{2}, \mathrm{NH}_{3}, \mathrm{CH}_{4}, \mathrm{H}$, and $\mathrm{CO}$. Octane retained $35 \mathrm{~Hz}$ shift in frequency in $5 \mathrm{~s}$ response time. This has highlighted the selectivity of the sensor towards octane was relatively higher towards toluene with $10 \mathrm{~Hz}$ frequency change [123]. Consales et al. on the other hand presented work on QCM sensor with SWCNTs coating to toluene [124]. However, a frequency shift of $40 \mathrm{~Hz}$ was obtained when the sensor was exposed to a higher gas concentration with a longer response time reached ( $8 \mathrm{~min}$ ). The results analysed showed only $0.9 \mathrm{~Hz} / \mathrm{ppm}$ sensitivity of the QCM sensor towards toluene. Related works are summarised and reviewed in Table 6.

\subsection{Polymer with composites}

A study by Lal and Tiwari reported on $\mathrm{ZnO}$ thin film doped with calcium to coat a langasite SAW sensor in detecting carbon dioxide $\mathrm{CO}_{2}$ at high temperature [125]. The use of langasite allows the SAW sensor to maintain the piezoelectricity up to a very high temperature. The authors elucidated the chemo-resistive adsorption in addressing the sensing properties at high temperature [125]. Langasite is a promising material for the SAW sensor to work at higher temperature as compared to the temperature of pure $\mathrm{ZnO}$ thin film able to withstand [125]. The highest frequency shift $2.469 \mathrm{kHz}$ of $\mathrm{CO}_{2}$ sensing was observed when operating at $400{ }^{\circ} \mathrm{C}$ and exposed 
Table 5

Biopolymer coated sensors in detecting VOCs.

\begin{tabular}{|c|c|c|c|c|c|c|c|c|}
\hline \multicolumn{3}{|l|}{ Design parameters } & \multirow[b]{2}{*}{$\begin{array}{l}\text { Analyte gas } \\
\text { concentration }\end{array}$} & \multirow[b]{2}{*}{ Frequency shift } & \multirow[b]{2}{*}{$\begin{array}{l}\text { Response time and } \\
\text { sensitivity }\end{array}$} & \multirow{2}{*}{ Strengths } & \multirow{2}{*}{ Limitations } & \multirow{2}{*}{ References } \\
\hline Sensing material & Sensor & Target analytes & & & & & & \\
\hline \multirow{30}{*}{ Chitosan (Drop casting) } & \multirow{30}{*}{$\begin{array}{l}5 \mathrm{MHz} \text { AT-cut QCM } \\
\text { gold electrode }\end{array}$} & \multirow{5}{*}{ Methylamine } & $\begin{array}{l}1.63 \mathrm{mg} \mathrm{L}^{-1} \\
2.28 \mathrm{mg} \mathrm{L}^{-1}\end{array}$ & $\begin{array}{l}\sim 175 \mathrm{~Hz} \\
\sim 500 \mathrm{~Hz}\end{array}$ & \multirow{6}{*}{$384.70 \mathrm{~Hz} / \mathrm{mgL}^{-1}$} & Good mechanical & Less selective towards & \multirow{30}{*}{ [47] } \\
\hline & & & $\begin{array}{l}2.28 \mathrm{mg} \mathrm{L}^{-1} \\
3.25 \mathrm{mg} \mathrm{L}^{-1}\end{array}$ & $\begin{array}{l}\sim 500 \mathrm{~Hz} \\
\sim 750 \mathrm{~Hz}\end{array}$ & & strength & the alcohol group & \\
\hline & & & $4.88 \mathrm{mg} \mathrm{L}^{-1}$ & $\sim 1250 \mathrm{~Hz}$ & & Good film forming & The reproducibility and & \\
\hline & & & $6.5 \mathrm{mg} \mathrm{L}^{-1}$ & $\sim 2000 \mathrm{~Hz}$ & & properties & reversibility of the & \\
\hline & & & $0.34 \mathrm{mg} \mathrm{L}^{-1}$ & $\sim 50 \mathrm{~Hz}$ & & & sensor is less accurate. & \\
\hline & & \multirow{5}{*}{ Dimethylamine } & $0.84 \mathrm{mg} \mathrm{L}^{-1}$ & $\sim 100 \mathrm{~Hz}$ & & & & \\
\hline & & & $1.68 \mathrm{mg} \mathrm{L}^{-1}$ & $\sim 200 \mathrm{~Hz}$ & \multirow{4}{*}{$160.96 \mathrm{~Hz} / \mathrm{mgL}^{-1}$} & & & \\
\hline & & & $2.53 \mathrm{mg} \mathrm{L}^{-1}$ & $\sim 400 \mathrm{~Hz}$ & & & & \\
\hline & & & $3.37 \mathrm{mg} \mathrm{L}^{-1}$ & $\sim 500 \mathrm{~Hz}$ & & & & \\
\hline & & & $4.21 \mathrm{mg} \mathrm{L}^{-1}$ & $\sim 800 \mathrm{~Hz}$ & & & & \\
\hline & & \multirow{6}{*}{ Diethylamine } & $12.78 \mathrm{mg} \mathrm{L}^{-1}$ & $\sim 10 \mathrm{~Hz}$ & \multirow{4}{*}{$7.12 \mathrm{~Hz} / \mathrm{mgL}^{-1}$} & & & \\
\hline & & & $31.95 \mathrm{mg} \mathrm{L}^{-1}$ & $\sim 100 \mathrm{~Hz}$ & & & & \\
\hline & & & $44.74 \mathrm{mg} \mathrm{L}^{-1}$ & $\sim 225 \mathrm{~Hz}$ & & & & \\
\hline & & & $63.91 \mathrm{mg} \mathrm{L}^{-1}$ & $\sim 400 \mathrm{~Hz}$ & & & & \\
\hline & & & $95.86 \mathrm{mg} \mathrm{L}^{-1}$ & $\sim 900 \mathrm{~Hz}$ & \multirow{5}{*}{$7.22 \mathrm{~Hz} / \mathrm{mgL}^{-1}$} & & & \\
\hline & & & $7.18 \mathrm{mg} \mathrm{L}^{-1}$ & $\sim 80 \mathrm{~Hz}$ & & & & \\
\hline & & \multirow{3}{*}{ Methyl alcohol } & $14.4 \mathrm{mg} \mathrm{L}^{-1}$ & $\sim 120 \mathrm{~Hz}$ & & & & \\
\hline & & & $28.7 \mathrm{mg} \mathrm{L}^{-1}$ & $\sim 250 \mathrm{~Hz}$ & & & & \\
\hline & & & $50.2 \mathrm{mg} \mathrm{L}^{-1}$ & $\sim 350 \mathrm{~Hz}$ & & & & \\
\hline & & \multirow{7}{*}{ Ethyl alcohol } & $63.9 \mathrm{mg} \mathrm{L}^{-1}$ & $\sim 450 \mathrm{~Hz}$ & & & & \\
\hline & & & $5.6 \mathrm{mg} \mathrm{L}^{-1}$ & $\sim 50 \mathrm{~Hz}$ & \multirow{5}{*}{$19.35 \mathrm{~Hz} / \mathrm{mgL}^{-1}$} & & & \\
\hline & & & $11.3 \mathrm{mg} \mathrm{L}^{-1}$ & $\sim 200 \mathrm{~Hz}$ & & & & \\
\hline & & & $16.9 \mathrm{mg} \mathrm{L}^{-1}$ & $\sim 300 \mathrm{~Hz}$ & & & & \\
\hline & & & $22.6 \mathrm{mg} \mathrm{L}^{-1}$ & $\sim 450 \mathrm{~Hz}$ & & & & \\
\hline & & & $28.2 \mathrm{mg} \mathrm{L}^{-1}$ & $\sim 500 \mathrm{~Hz}$ & & & & \\
\hline & & & $39.5 \mathrm{mg} \mathrm{L}^{-1}$ & $\sim 800 \mathrm{~Hz}$ & & & & \\
\hline & & \multirow{3}{*}{ Isopropyl alcohol } & $17.86 \mathrm{mg} \mathrm{L}^{-1}$ & $\sim 60 \mathrm{~Hz}$ & \multirow{3}{*}{$4.06 \mathrm{~Hz} / \mathrm{mgL}^{-1}$} & & & \\
\hline & & & $35.73 \mathrm{mg} \mathrm{L}^{-1}$ & $\sim 150 \mathrm{~Hz}$ & & & & \\
\hline & & & $\begin{array}{l}50 \mathrm{mg} \mathrm{L}^{-1} \\
71.45 \mathrm{mg} \mathrm{L}^{-1}\end{array}$ & $\sim 200 \mathrm{~Hz}$ & & & & \\
\hline & & \multirow{5}{*}{ Ethanol } & $\begin{array}{l}71.45 \mathrm{mg} \mathrm{L}^{-1} \\
107.18 \mathrm{mg} \mathrm{L}^{-1}\end{array}$ & $\begin{array}{l}\sim 300 \mathrm{~Hz} \\
\sim 450 \mathrm{~Hz}\end{array}$ & \multirow{5}{*}{$0.4 \mathrm{~Hz} / \mathrm{mgL}^{-1}$} & & & \\
\hline \multirow{4}{*}{ Chitosan (Dip coating) } & \multirow{4}{*}{$\begin{array}{l}10 \mathrm{MHz} \text { AT-cut QCM } \\
\text { gold electrode }\end{array}$} & & & $3 \mathrm{~Hz}$ & & \multirow{4}{*}{$\begin{array}{l}\text { Good } \\
\text { hydrophilicity }\end{array}$} & This method uses a & \\
\hline & & & & & & & QCM with higher & \\
\hline & & & $7 \mathrm{mgL}^{-1}$ & & & & resonant frequency but & [112] \\
\hline & & & & & & & $\begin{array}{l}\text { giving on } 40 \mathrm{~Hz} \text { of shift } \\
\text { in the frequency }\end{array}$ & \\
\hline
\end{tabular}

$5 \mathrm{MHz}$ AT-cut QCM

Methyl alcoho

$28.7 \mathrm{mg} \mathrm{L}^{-1}$

$7 \mathrm{mgL}$

esonant frequency but

in the frequency 
n-propanol

n-amyl alcoho

isoamyl alcohol
$5 \mathrm{~Hz}$

$39 \mathrm{~Hz}$

$24 \mathrm{~Hz}$
$0.9 \mathrm{~Hz} / \mathrm{mgL}^{-1}$

$4.4 \mathrm{~Hz} / \mathrm{mgL}^{-1}$ (42

response time)

$3.1 \mathrm{~Hz} / \mathrm{mgL}^{-1}$
Simple setup and easy

to replicate.

Promotes a path for

chitosan to

attached onto the

electrodes of the

QCM via covalent

High sensitivity

towards hexanal

$\begin{array}{ll}6 \mathrm{ppm} & 6 \mathrm{~Hz} \\ 2 \mathrm{ppm} & 15 \mathrm{~Hz} \\ 1 \mathrm{ppm} & 19 \mathrm{~Hz}\end{array}$

$\begin{array}{ll}6 \mathrm{ppm} & 6 \mathrm{~Hz} \\ 2 \mathrm{ppm} & 15 \mathrm{~Hz} \\ 1 \mathrm{ppm} & 19 \mathrm{~Hz}\end{array}$

$\begin{array}{ll}1 \mathrm{ppm} & 19 \mathrm{~Hz} \\ 1 \mathrm{ppm} & 33 \mathrm{~Hz}\end{array}$

Non-coated: $\quad$ Non-coated

$20 \mathrm{ppm} \quad 5 \mathrm{~Hz}$

$2 \mathrm{ppm} \quad 2 \mathrm{~Hz}$

Pegylated polymer (Drop casting)

$5 \mathrm{~Hz}$
$2 \mathrm{~Hz}$

$2 \mathrm{~Hz}$
$9 \mathrm{~Hz}$
$9 \mathrm{~Hz}$

$\begin{array}{ll}\text { Coated with } & \text { Coated with } \\ \text { carboxyl: } & \text { carboxyl: }\end{array}$

$\begin{array}{ll}\text { carboxyl: } & \text { carboxyl: } \\ 6 \mathrm{ppm} & 9 \mathrm{~Hz}\end{array}$

$6 \mathrm{ppm} \quad 19 \mathrm{~Hz}$

$\begin{array}{ll}1 \mathrm{ppm} & 35 \mathrm{~Hz} \\ 4 \mathrm{ppm} & 21 \mathrm{~Hz}\end{array}$

$\begin{array}{ll}4 \mathrm{ppm} & 21 \mathrm{~Hz} \\ \text { Coated with } & \text { Coated with }\end{array}$

succinyl: succinyl:

$6 \mathrm{ppm} \quad 25 \mathrm{~Hz}$

$8 \mathrm{ppm} \quad 39 \mathrm{~Hz}$

$\begin{array}{ll}2 \mathrm{ppm} & 69 \mathrm{~Hz} \\ 4 \mathrm{ppm} & 50 \mathrm{~Hz}\end{array}$ 
Table 6

Summary of the previous work on CNTs based coated sensors in detecting VOCs.

\begin{tabular}{|c|c|c|c|c|c|c|c|c|}
\hline \multicolumn{3}{|l|}{ Design parameters } & \multirow[b]{2}{*}{$\begin{array}{l}\text { Analyte gas } \\
\text { concentration }\end{array}$} & \multirow[b]{2}{*}{ Frequency shift } & \multirow[b]{2}{*}{$\begin{array}{l}\text { Response time and } \\
\text { sensitivity }\end{array}$} & \multirow{2}{*}{ Strengths } & \multirow{2}{*}{ Limitations } & \multirow{2}{*}{ References } \\
\hline Sensing material & Sensor & $\overline{\text { Target analytes }}$ & & & & & & \\
\hline \multirow[t]{7}{*}{ SWCNTs } & & & Exposure: & & $\begin{array}{l}\text { SWCNTs in ethanol } \\
(\mathrm{kHz} / \mathrm{ppm})\end{array}$ & Highly sensitive & & \\
\hline & & & $85 \mathrm{ppm}$ ethanol & & 6.89 & & & \\
\hline & & & $\begin{array}{l}178 \text { ppm ethyl } \\
\text { acetate }\end{array}$ & & 3.32 & & & \\
\hline & & & $93 \mathrm{ppm}$ toluene & & 3.17 & & & \\
\hline & & & $\begin{array}{l}\text { LOD: SWCNTs in } \\
\text { ethanol (ppm) }\end{array}$ & & $\begin{array}{l}\text { MWCNTs in ethanol } \\
\text { (kHz/ppm) }\end{array}$ & & & \\
\hline & $433.92 \mathrm{MHz}$ ST-X & & 1.3 & & 1.79 & & Selectivity depends on & \\
\hline & quartz oscillating SAW & $v_{\text {Ethanol ethyl acetate }}$ & $\begin{array}{l}2.7 \\
2.8\end{array}$ & - & 0.90 & & the type of CNTs & {$[118]$} \\
\hline \multirow[t]{12}{*}{ MWCNTs } & resonator & & $\begin{array}{l}2.8 \\
\text { MWCNTs in }\end{array}$ & & $\begin{array}{l}1.01 \\
\text { SWCNTs in toluene }\end{array}$ & Low limit of detection & deposited & \\
\hline & & & ethanol (ppm) & & $(\mathrm{kHz} / \mathrm{ppm})$ & & & \\
\hline & & & 10.0 & & 5.45 & & & \\
\hline & & & 9.0 & & 7.47 & & & \\
\hline & & & SWCNTs in toluene & & MWCNTs in toluene & & & \\
\hline & & & $\begin{array}{l}\text { (ppm) } \\
1.4\end{array}$ & & $\begin{array}{l}(\mathrm{KHZ} / \mathrm{PPM}) \\
0.87\end{array}$ & & & \\
\hline & & & 1.6 & & 1.73 & & & \\
\hline & & & 1.2 & & 2.02 & & & \\
\hline & & & $\begin{array}{l}\text { MWCNTs in } \\
\text { toluene (ppm) }\end{array}$ & & & & & \\
\hline & & & 10.2 & & & & & \\
\hline & & & 5.2 & & & & & \\
\hline & & & 4.4 & & & & & \\
\hline sWCNTs & $\begin{array}{l}433.92 \mathrm{MHz} \text { ST-X } \\
\text { quartz two-port SAW }\end{array}$ & $\begin{array}{l}\text { Ethanol ethyl acetate } \\
\text { toluene }\end{array}$ & $\begin{array}{l}1.06 \times 10^{-4} \mathrm{M}(11 \% \\
\mathrm{RH})\end{array}$ & $100 \mathrm{~Hz}$ & _- & Low limit of detection & $\begin{array}{l}\text { Selectivity depends on } \\
\text { the type of CNTs }\end{array}$ & [119] \\
\hline MWCNTs & resonator & & $\begin{array}{l}8.06 \times 10^{-4} \mathrm{M}(84 \% \\
\mathrm{RH})\end{array}$ & $500 \mathrm{~Hz}$ & & $\begin{array}{l}\text { Ambient working } \\
\text { temperature }\end{array}$ & deposited & \\
\hline \multirow[t]{2}{*}{ SWCNTs DWCNTs } & $\begin{array}{l}158 \mathrm{MHz} \text { ST-X cut } \\
\text { quartz SAW }\end{array}$ & Octane toluene & $25 \mathrm{ppm}$ & $\sim 30 \mathrm{~Hz}$ (octane) & $\sim 5 \mathrm{~s}$ & $\begin{array}{l}\text { Good selectivity } \\
\text { towards toluene and } \\
\text { octane }\end{array}$ & $\begin{array}{l}\text { Airbrush coating } \\
\text { technique failed to give } \\
\text { smooth and even }\end{array}$ & [123] \\
\hline & & & & $\sim 10 \mathrm{~Hz}$ (toluene) & $\sim 10 \mathrm{~s}$ & & dispersion & \\
\hline \multirow[t]{3}{*}{ CNTs } & $\begin{array}{l}286 \mathrm{MHz} \text { XY-cut } \\
\mathrm{LiNbO}_{3} \mathrm{SAW}\end{array}$ & Carbon dioxide & $3.5 \%$ & - & - & $\begin{array}{l}\text { Enhanced the } \\
\text { sensitivity of the } \\
\text { fabrication }\end{array}$ & Not reproducible & [142] \\
\hline & & & & & & $\begin{array}{l}\text { Simple CNTs growing } \\
\text { method }\end{array}$ & $\begin{array}{l}\text { Challenges in } \\
\text { repeatability }\end{array}$ & \\
\hline & & & $54 \mathrm{ppm}$ & $\sim 40 \mathrm{~Hz}$ & $8 \mathrm{~min}$ & & & \\
\hline SWCNTs & $10 \mathrm{MHz}$ AT-cut QCM & Toluene xylene & $3 \mathrm{ppm}$ & $\sim 15 \mathrm{~Hz}$ & $\begin{array}{l}\text { Toluene: }-0.9 \mathrm{~Hz} / \mathrm{ppm} \\
\text { Xylene: }-1.8 \mathrm{~Hz} / \mathrm{ppm}\end{array}$ & Excellent repeatability & & [124] \\
\hline
\end{tabular}



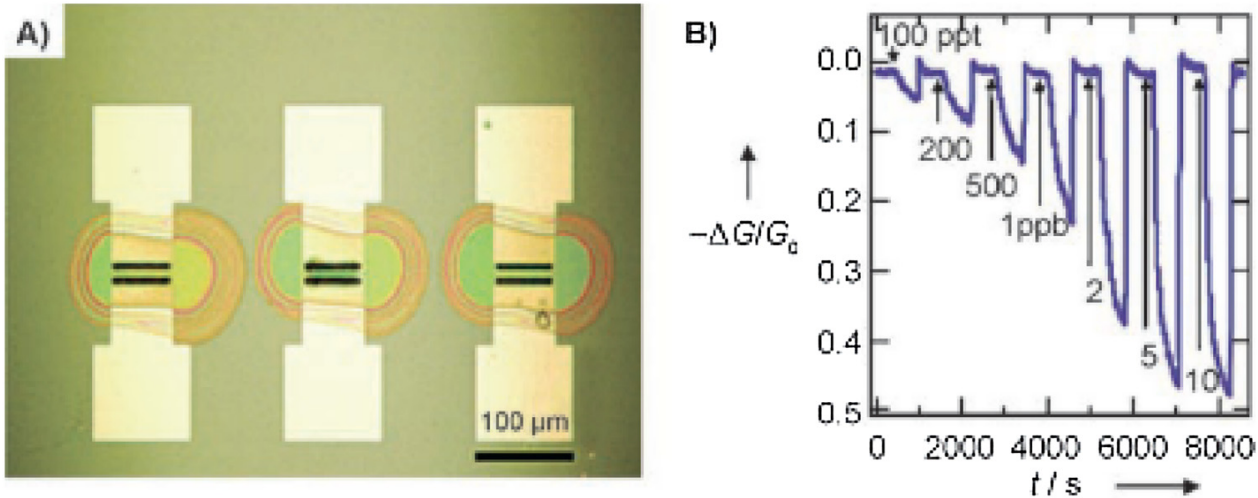

C)

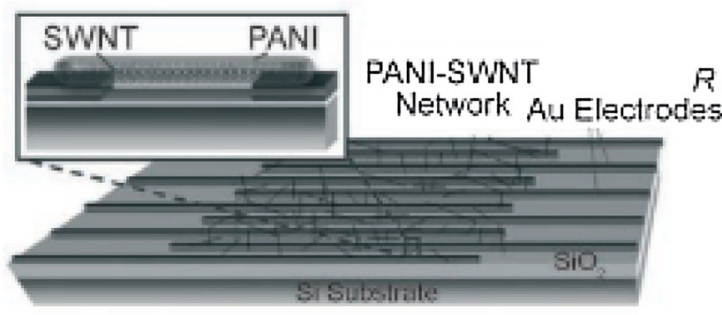

D)

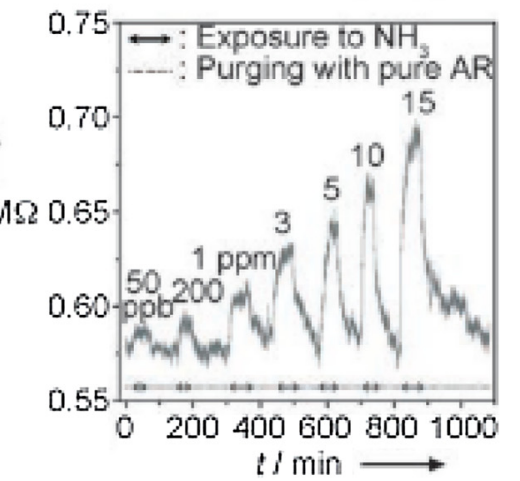

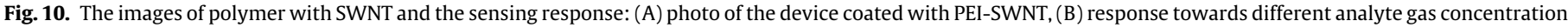

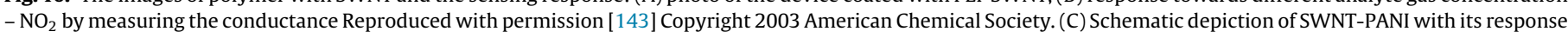
(D) to different concentration of analyte gas $\mathrm{NH}_{3}$. Reproduced with permission [144] Copyright 2006 Wiley.

to $25,000 \mathrm{ppm} \mathrm{CO}_{2}$ concentration. This work also promotes crosssensitivity of $\mathrm{H}_{2}$ and $\mathrm{CO}$ where $1.605 \mathrm{kHz}$ and $1.322 \mathrm{kHz}$ were obtained respectively from contact with 500 ppm gas concentration. Aside from calcium, nanoclay doped with a synthetic polymer $\mathrm{PECH}$ was found to provide good results in detecting analyte gases [126]. It is observed that a reduction in the roughness of the surface of the undoped PECH has improved the sensor performance. Surface roughness often associated with the surface area. A very rough surface will prevent effective adsorption and drops the sensing performance. However, the absence of a good amount of roughness to the surface of the sensing layer reduces the gas adsorption site which eventually results in poor sensing performance. This is based on the attenuation coefficient of the analyte gas to the sensing material. It can be deduced that optimum surface roughness is essential in providing a greater site for effective adsorption. Nanoclay doped PECH gives a roughness value RMS of about $129.280 \mathrm{~nm}$ and average roughness of approximately $135.927 \mathrm{~nm}$. It produces highest sensor response at $17.446 \mathrm{~Hz}$ followed by doped collodion (RMS $\sim 115.860 \mathrm{~nm}$ and average roughness $\sim 123.112 \mathrm{~nm}$ ) and doped alkyd resin (RMS $\sim 128.101 \mathrm{~nm}$ and average roughness $\sim$ $131.431 \mathrm{~nm}$ ) at $6.174 \mathrm{~Hz} 12.890 \mathrm{~Hz}$ correspondingly [126].

Ma et al., investigated the in functionalization of the organic/inorganic nanocomposites to chitosan film - chitosan $/ \mathrm{ZnO} / \mathrm{CuO}$ in the attempt to improve the sensing performance [127]. The morphological image is shown in Fig. 11. As there is a presence of oxides in the functionalized material, the sensing process requires a high working temperature. Although this sensing material did not work at ambient temperature, chitosan showed a good film-forming property and good biocompatibility that enabled the organic/inorganic nanocomposites to uphold more functionalities [127]. The investigation suggested for more extensive studies needed to be conducted in looking at different composites and/or combination of polymer with chitosan for different groups of VOCs [127]. Besides polymers, metal oxides are also commonly functionalised with CNTs in improving sensor performance [128].

Another study by Sayago et al., examined the characteristics of $69 \mathrm{MHz}$ SAW sensors with embedded iron(II, III) oxide $\left(\mathrm{Fe}_{3} \mathrm{O}_{4}\right)$ nanoparticles on the polymer polyethyleneimine (PEI) sensitive layer [129]. The sensors performance was investigated by assessing the effect of different nanoparticles (NPs) concentration and different thickness on the sensitivity of the sensor [129]. The concentration of the NPs was fixed at $0.4 \mathrm{mg} / \mathrm{mL}$ with thickness at 13 $\mathrm{nm}$ and $7 \mathrm{~nm}$. The thicker sensing layer gives slightly lower sensitivity regardless of the types of VOC exposed to the sensor (ethanol; $0.97 \mathrm{~Hz} / \mathrm{ppm}$, methanol; $0.81 \mathrm{~Hz} / \mathrm{ppm}$ and toluene; $1.43 \mathrm{~Hz} / \mathrm{ppm}$ ) than $7 \mathrm{~nm}$ sensing layer (ethanol; $1.63 \mathrm{~Hz} / \mathrm{ppm}$, methanol; 1.00 $\mathrm{Hz} / \mathrm{ppm}$, and $1.94 \mathrm{~Hz} / \mathrm{ppm}$ ) [129]. The work also presented findings that with the increase in NPs concentration from $0.2 \mathrm{mg} / \mathrm{mL}$, $0.4 \mathrm{mg} / \mathrm{mL}$ and $0.8 \mathrm{mg} / \mathrm{mL}$, the sensitivity of the sensor increased persistently as it gives linear relationship to gas molecules adsorption. From the results obtained, the authors concluded that the frequency shift and sensitivity of the SAW sensors increased with increasing NPs concentration embedded in the polymer at a fixed NP dimension [129]. The smallest concentration of NPs used was claimed to give the best results as it led to the largest frequency shift, highest sensitivity, lowest noise, lowest limit of detection and shortest response time for all VOCs detected [129]. Another research on SAW sensor with PEI embedded with $\mathrm{SiO}_{2} / \mathrm{Si}$ NPs and MWCNTs for detecting ethanol, methanol and toluene has been conducted by Viespe and Grigoriu [130]. The results showed a better sensing performance when PEI is embedded with MWCNTs as compared to NPs when exposed to 1600 ppm gas. This can be justified by the structural properties of MWCNTs which has provided greater specific surface area as compared to $\mathrm{SiO}_{2} / \mathrm{Si} \mathrm{NPs} \mathrm{[130].} \mathrm{Thus,}$ it improved the adsorption mechanism of the sensing layer. Previous works on having polymers functionalised with CNTs on PIB, 


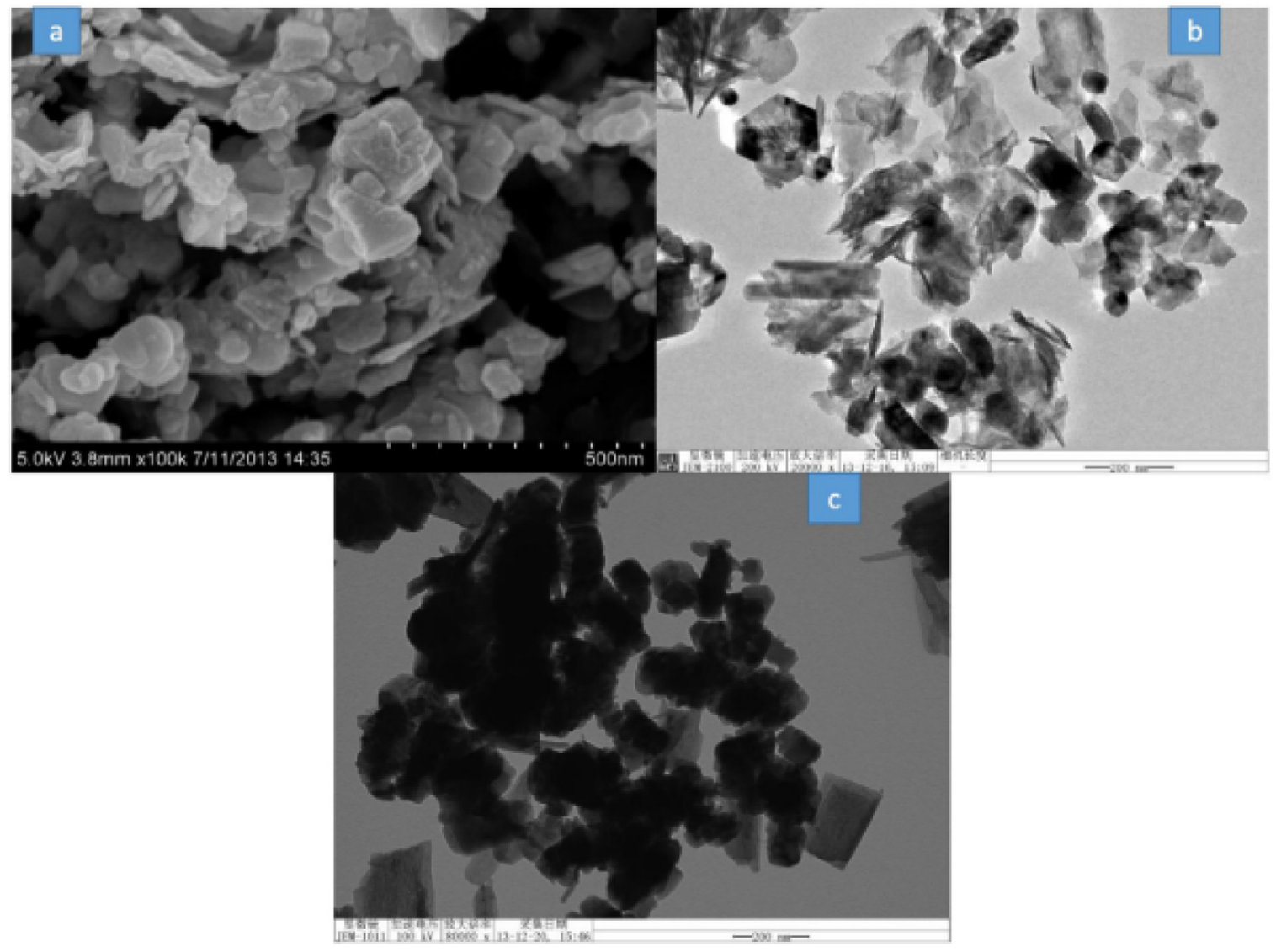

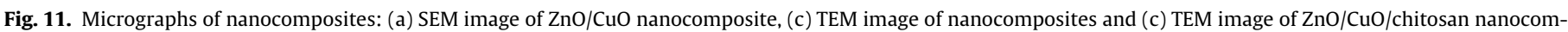
posite. Reproduced with permission [127] Copyright 2016 Elsevier Inc.

PECH, and PEUT have been done with the aim to increase the sensitivity of the sensor [130-132].

Work is done by Ayad et al., and Wang et al., were on the functionalisation of the conductive polymers PANI and PEI to aid in the performance of the chitosan-based QCM sensor respectively. The use of both PANI [111] and PEI [50] with chitosan have tremendously improved the performance of the sensor. However, the properties of the polymer used to functionalize with chitosan play a crucial role in determining the selectivity of the sensing layer. Both PANI and PEI showed a strong selectivity towards amines and aldehydes, respectively. The use of chitosan functionalised with PANI and PEI aids in the interconnectivity and provides greater surface area for the adsorption process and rapid response for analyte detection that the measurement can be recorded within seconds [50]. Ayad et al. highlighted the improvement of the QCM sensor by using doped and dedoped Chitosan/PANI sensing layer in detecting amine compounds and alcohols. The sensitivity of the sensor has greatly increased from $26.23 \mathrm{~Hz} / \mathrm{mgL}^{-1}$ for methylamine and $22.2 \mathrm{~Hz} / \mathrm{mgL}^{-1}$ to $251.5 \mathrm{~Hz} / \mathrm{mgL}^{-1}$ and $449 \mathrm{~Hz} / \mathrm{mgL}^{-1}$ respectively for amines and alcohols [111]. This result is illustrating the selectivity of the sensing layer towards amine compounds as it only improved the sensitivity towards ethyl alcohol by about double the dedoped chitosan/PANI at $3.4 \mathrm{~Hz} / \mathrm{mgL}^{-1}$. However, more studies are required in combining the conducting polymers to chitosan for various groups of gases for the purpose of validating the chemical interactions between the analyte gas and the sensing layer. Fig. 12 shows the images of chitosan biopolymer modified with PEI while Fig. 13 shows the sensing mechanism when polymer with composite is used as the sensing layer.

Another composite involves the use of carbon-based composite. Graphene is a carbon-based material which provides a porous mesh structure to the sensing layer, enhancing the sensitivity of the sensor as there is presence of greater surface area for adsorption to occur. A work by Zhang et al. has functionalised and deposited graphene with chitosan onto a QCM device in detecting amine vapours that are methylamine MA, dimethylamine DMA and trimethylamine TMA with molecular mass of the amine vapours increases in the sequence of MA, DMA and TMA [133]. Gas analyte of concentration range from $5 \mathrm{ppm}$ to $150 \mathrm{ppm}$ was exposed to the sensor which then signifies highest sensitivity of the QCM sensor towards TMA. This may reflect the influence of both structural formula and molecular mass of the molecules. The sensitivity of the sensor towards amine vapours rises following the order; $2.3 \mathrm{~Hz} / \mathrm{ppm}$ for DMA, $2.7 \mathrm{~Hz} / \mathrm{ppm}$ for MA and $4.8 \mathrm{~Hz} / \mathrm{ppm}$ for TMA [133]. The molecular mass does not apply to DMA detection. Hence, more study needs to be done regarding the orientation of the molecule in terms of molecular structure and bonding in obtaining effective adsorption. Modifying the graphene oxide with chitosan improved the performance of the sensor as compared to just having graphene oxide as the sensing layer [133]. Carbon-based material in most work showed a better performance in gas detection compared to the oxides [133]. High sensitivity can be obtained as the carbon-based composite typically provides a large surface area for adsorption. Besides, Zhang et al. also reported that graphene oxide/ chitosan is selective towards amine vapours when tested with other gases ( 50 ppm of ethanol, acetone, toluene, n-hexane, ethyl acetate) with all frequency shifts fall below $20 \mathrm{~Hz}$. Amine vapours give shifts of $95 \mathrm{~Hz}, 83 \mathrm{~Hz}$, and $180 \mathrm{~Hz}$ for MA, DMA and TMA consequently [133]. However, carbon-based composite does not provide a good selectivity towards the analytes with low adsorption energy due to the absence of chemical reactions [64]. Based on the analysis, carbon-based material is commonly used as a composite to other 

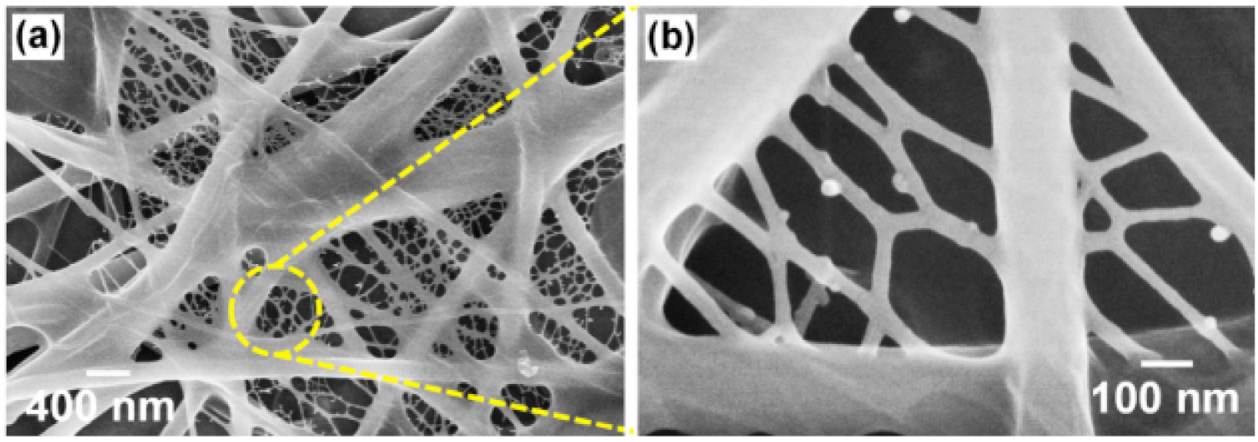

Fig. 12. SEM images of chitosan/PEI membrane Reproduced with permission [50] Copyright 2014 Elsevier Inc.

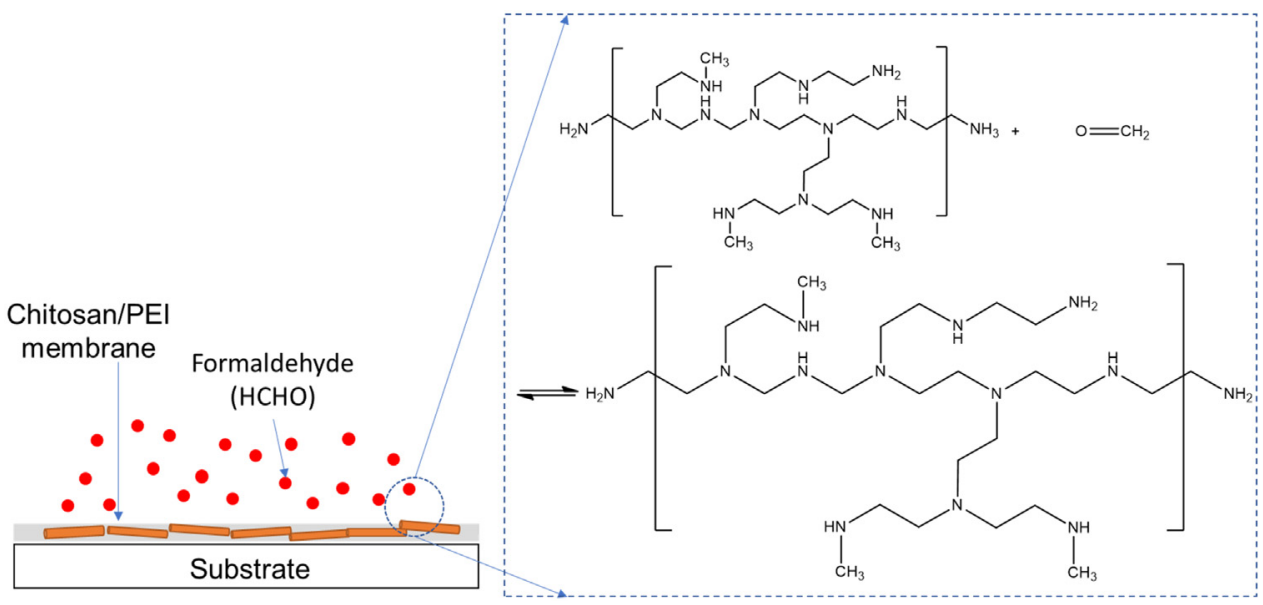

Fig. 13. Schematic illustration of the sensing mechanism of formaldehyde vapour on chitosan/PEI membrane [50].

bases due to the limitation in being selective. Hence, the use of polymer coating attracted the researchers' attention as a polymer is claimed to be more versatile in terms of the ability to be functionalised in accordance to the required purpose. Previous works on carbon-based composites also emphasised the enhancement in sensor performance [134-137].

In another work, chitosan has been used to overlay a cellulose acetate on a QCM device in detecting acetic anhydride vapour at different concentrations [138]. The experimental results show a promising method to enhance the performance of the device with a low limit of detection of acetic anhydride (5 ppm) [138]. This surface modification by overlaying materials on to the sensing device may be implemented in future work on synthesizing a high selectivity and sensitivity device. The related work has been summarised and reviewed in Table 7 .

\section{Limitation and challenges}

Lung cancer cases emerged as one of the diseases with a high mortality rate, an alternative to screening and early detection is crucial in increasing the survival rate. Sensor-based diagnosis, the acoustic wave sensors have a high potential in providing good portability, highly sensitive and fast responding detection method. It also does not require an expert to operate. In improving the sensor performance, the sensing material plays a critical role. The major components of the sensing materials are oxides, CNTs, synthetic polymers, biopolymers and composites.

The high working temperature of oxides and less selectivity of CNTs inhibits the purpose of having a high-performance device. For instance, $10 \mathrm{MHz}$ of AT-cut QCM with SWCNTs as the sensing layer gives only $0.9 \mathrm{~Hz} / \mathrm{ppm}$ sensitivity towards $54 \mathrm{ppm}$ toluene detection [123]. However, MIP coating has increased the sensitivity of the sensor about $2.147 \mathrm{~Hz} / \mathrm{ppm}$ towards toluene analyte with a significantly lower concentration of $1.25 \mathrm{ppm}$ [87]. This has drawn the attention of the researcher in developing polymer-based sensors. However, the polymer-based sensor itself requires improvement by having hybrids. Slight change to the composition of the polymer may result in improved sensing performance. This can be justified with PANI (EB) and PANI (ES) on $5 \mathrm{MHz}$ QCM sensor exposed to $5 \mathrm{ppm}$ methanol. The frequency shift of the sensor towards methanol has escalated from $40 \mathrm{~Hz}$ [90] to $120 \mathrm{~Hz}$ consequently [44]. Functionalisation of the hybrids determined the selectivity and sensitivity of the sensor. Oxides may promote high selectivity, CNTs may provide higher sensitivity while polymers are being versatile and flexible to be functionalised with other materials. Hybrid sensing material enables the mix of any or all the components to form a high-performance sensing device. Materials selection improves selectivity as different mechanisms favour in selective analyte gas. $\mathrm{PEI} / \mathrm{Fe}_{3} \mathrm{O}_{4}$ provides greater sensitivity $(1.94 \mathrm{~Hz} / \mathrm{ppm})$ [129] towards toluene rather than $\mathrm{PEI}-\mathrm{SiO}_{2} / \mathrm{Si}(0.87 \mathrm{~Hz} / \mathrm{ppm})$ and PEI-MWCNTs $(1.23 \mathrm{~Hz} / \mathrm{ppm})$ [130]. This stresses that functionalisation of a sensing material is important in determining the selectivity and sensitivity of a sensor.

Biopolymers are discovered to exhibit a good sensing performance aside from preventing any harsh effects on the environment as they are compostable and biodegradable. For example, the use of chitosan/ PANI composite on QCM sensor has improved the sensing performance of the sensor in detecting alcohol (ethanol at $7 \mathrm{mgL}^{-1}$ ) compared to monolayer chitosan. The sensitivity of the sensor had risen by about 8 times, from $0.4 \mathrm{~Hz} / \mathrm{mgL}^{-1}$ 
Table 7

Summary of the previous work on polymer with composites sensors in detecting VOCs.

\begin{tabular}{|c|c|c|c|c|c|c|c|c|}
\hline \multicolumn{3}{|l|}{ Design parameters } & \multirow[b]{2}{*}{$\begin{array}{l}\text { Analyte gas } \\
\text { concentration }\end{array}$} & \multirow[b]{2}{*}{ Frequency shift } & \multirow[b]{2}{*}{$\begin{array}{l}\text { Response time and } \\
\text { sensitivity }\end{array}$} & \multirow[t]{2}{*}{ Strengths } & \multirow{2}{*}{ Limitations } & \multirow{2}{*}{ References } \\
\hline Sensing material & Sensor & Target analytes & & & & & & \\
\hline \multirow{4}{*}{$\begin{array}{l}\text { Calcium doped } \mathrm{ZnO} \\
\text { thin film }\end{array}$} & \multirow{4}{*}{$\begin{array}{l}\text { Langasite } 9.1 \mathrm{MHz} \text { SAW } \\
\text { Platinum IDTs }\end{array}$} & \multirow{2}{*}{$\mathrm{CO}_{2}$} & $25,000 \mathrm{ppm}$ & $2.469 \mathrm{kHz}$ & $87 \mathrm{~s}$ & \multirow{4}{*}{$\begin{array}{l}\text { Promotes } \\
\text { cross-sensitivity of } \mathrm{H}_{2} \\
\text { and } \mathrm{CO} \text { at high } \\
\text { temperature }\left(400{ }^{\circ} \mathrm{C}\right) \\
\text { Good surface adhesion } \\
\text { as compared to } \\
\text { undoped polymer }\end{array}$} & \multirow{3}{*}{$\begin{array}{l}\text { High optimum } \\
\text { temperature lead to } \\
\text { high power usage }\end{array}$} & \multirow{3}{*}{ [125] } \\
\hline & & & 5000 ppm & $1.031 \mathrm{kHz}$ & $53 \mathrm{~s}$ & & & \\
\hline & & $\begin{array}{l}\mathrm{CO} \\
\mathrm{H}_{2}\end{array}$ & $500 \mathrm{ppm}$ & $1.605 \mathrm{kHz}$ & $\begin{array}{l}87 \mathrm{~s} \\
68 \mathrm{~s}\end{array}$ & & & \\
\hline & & & & Undoped: & $\begin{array}{l}60 \mathrm{~s} \text { response time at } \\
15 \% \mathrm{wt} \% \text { doped }\end{array}$ & & $\begin{array}{l}\text { Good surface adhesion } \\
\text { as compared to }\end{array}$ & \multirow{3}{*}{ [126] } \\
\hline \multirow[t]{5}{*}{ Nanoclay doped PECH } & \multirow[t]{2}{*}{$\begin{array}{l}10 \mathrm{MHz} \text { AT-cut gold } \\
\text { plated QCM }\end{array}$} & \multirow[t]{2}{*}{$\begin{array}{l}\text { Sulphur mustard (toxic } \\
\text { gas) }\end{array}$} & \multirow{2}{*}{$\begin{array}{l}0.17 \mathrm{ppm} \text { (lowest } \\
\text { concentration } \\
\text { detected) }\end{array}$} & $\begin{array}{l}6.823 \mathrm{~Hz} \\
\text { Doped by nanoclay } \\
\text { wt\%): }\end{array}$ & & $\begin{array}{l}\text { undoped polymer } \\
\text { Film uniformity }\end{array}$ & $\begin{array}{l}\text { undoped polymer } \\
\text { Film uniformity }\end{array}$ & \\
\hline & & & & $1.173 \mathrm{kHz}(5 \%)$ & & $\begin{array}{l}\text { Able to detect analyte } \\
\text { at low concentration }\end{array}$ & $\begin{array}{l}\text { Able to detect analyte at } \\
\text { low concentration }\end{array}$ & \\
\hline & \multirow{8}{*}{$6 \mathrm{MHz}$ AT-cut QCM } & & & $3.234 \mathrm{kHz}(10 \%)$ & & \multirow{3}{*}{ Increased in sensitivity } & \multirow{3}{*}{ Increased in sensitivity } & \multirow{8}{*}{ [127] } \\
\hline & & & & $17.446 \mathrm{kHz}(12.5 \%)$ & & & & \\
\hline & & & & $\begin{array}{l}4.673 \mathrm{kHz}(15 \%) \\
4.304 \mathrm{kHz}(20 \%)\end{array}$ & & & & \\
\hline \multirow{5}{*}{$\begin{array}{l}\mathrm{ZnO} / \mathrm{CuO} / \text { Chitosan } \\
\text { (Drop casting) }\end{array}$} & & Toluene & & & & Improves greatly the & Challenges in & \\
\hline & & & - & - & - & $\begin{array}{l}\text { adsorption properties } \\
\text { as compared to the }\end{array}$ & $\begin{array}{l}\text { desorbing the analyte } \\
\text { gas because of the }\end{array}$ & \\
\hline & & Formaldehyde & & & & $\begin{array}{l}\text { organic/inorganic } \\
\text { nanocomposites on its }\end{array}$ & $\begin{array}{l}\text { strong both chemical } \\
\text { interaction and/or }\end{array}$ & \\
\hline & & Dichloromethane & & & & own & reaction & \\
\hline & & Cyclohexanone & & & & $\begin{array}{l}\text { Good performance for } \\
\text { different types of } \\
\text { analytes }\end{array}$ & & \\
\hline \multirow{6}{*}{ SWCNTs/CdA } & \multirow{6}{*}{$\begin{array}{l}315 \text { and } 433 \mathrm{MHz} \text { two } \\
\text { port ST-X quartz SAW } \\
\text { resonator }\end{array}$} & $\begin{array}{l}\text { SAW } 315 \mathrm{MHz} \\
\text { Ethanol }\end{array}$ & 1.1 & & & \multirow{6}{*}{$\begin{array}{l}\text { High sensitivity } \\
\text { towards organic } \\
\text { vapours }\end{array}$} & \multirow{6}{*}{$\begin{array}{l}\text { Improve in sensitivity } \\
\text { via increase in resonant } \\
\text { frequency of the sensor } \\
\text { instead of } \\
\text { improvement in the } \\
\text { functionalisation of the } \\
\text { coating }\end{array}$} & \multirow{6}{*}{ [134] } \\
\hline & & Ethylacetate & 1.0 & & $20.05 \mathrm{~Hz} / \mathrm{ppm}$ & & & \\
\hline & & $\begin{array}{l}\text { Toluene } \\
\text { SAW } 433 \mathrm{MHz}\end{array}$ & 0.6 & - & & & & \\
\hline & & $\begin{array}{l}\text { SAW } 433 \mathrm{MHHZ} \\
\text { Ethanol }\end{array}$ & 0.7 & & $39.0 \mathrm{~Hz} / \mathrm{ppm}$ & & & \\
\hline & & Ethylacetate & 0.9 & & & & & \\
\hline & & Toluene & 0.7 & & $43.7 \mathrm{~Hz} / \mathrm{ppm}$ & & & \\
\hline \multirow[t]{4}{*}{$\mathrm{MWCNTs} / \mathrm{CeO}_{2}$} & \multirow[t]{4}{*}{$\begin{array}{l}434 \mathrm{MHz} \text { AT quartz } \\
\text { SAW sensor }\end{array}$} & Acetone & $45 \%$ & $200 \mathrm{kHz}$ & & \multirow{4}{*}{$\begin{array}{l}\text { Higher sensitivity } \\
\text { towards acetone } \\
\text { Promotes the use of } \\
\text { semi-conducting } \\
\text { sensing material }\end{array}$} & $\begin{array}{l}\text { Sample preparation } \\
\text { requires high }\end{array}$ & [136] \\
\hline & & Ethanol & & & & & $\begin{array}{l}\text { temperature, up to } 500 \\
\text { and } 800^{\circ} \mathrm{C}\end{array}$ & \\
\hline & & SAW Ethanol & 0.23 & - & $131.84 \mathrm{~Hz} / \mathrm{ppm}$ & & & \\
\hline & & Ethylacetate & 0.69 & - & $\sim 40.0 \mathrm{~Hz}$ & & & \\
\hline SWCNTs in Cadmium & $\begin{array}{l}315,433,915 \mathrm{MHz} \\
\text { SAW resonator and } 10 \\
\text { MHz AT-cut OCM }\end{array}$ & $\begin{array}{l}\text { Toluene } \\
\text { QCM }\end{array}$ & 0.20 & - & $144.7 \mathrm{~Hz} / \mathrm{ppm}$ & $\begin{array}{l}\text { Very low limit of } \\
\text { detection }\end{array}$ & & [115] \\
\hline
\end{tabular}




\begin{tabular}{|c|c|c|c|c|c|c|c|c|}
\hline & & Ethanol & $1-180$ ppm & - & $0.32 \mathrm{~Hz} / \mathrm{ppm}$ & & & \\
\hline & & Ethylacetate & $1-500 \mathrm{ppm}$ & - & $0.15 \mathrm{~Hz} / \mathrm{ppm}$ & & & \\
\hline & & Toluene & $1-150 \mathrm{ppm}$ & - & $0.29 \mathrm{~Hz} / \mathrm{ppm}$ & & & \\
\hline \multirow{23}{*}{$\mathrm{PEI} / \mathrm{Fe}_{3} \mathrm{O}_{4}$} & \multirow{23}{*}{$\begin{array}{l}69 \mathrm{MHz} \text { ST-X cut } \\
\text { quartz SAW }\end{array}$} & Ethanol & $\begin{array}{l}\text { PEI only }(0 \mathrm{nmNP} \\
\text { diameter, } 0 \mathrm{mg} / \mathrm{mL}) \text { : }\end{array}$ & \multirow[t]{23}{*}{$\begin{array}{l}- \\
-\end{array}$} & & \multirow{23}{*}{$\begin{array}{l}\text { Fast response time ( } 9 \mathrm{~s} \\
\text { response time) }\end{array}$} & High limit of detection & \multirow{23}{*}{ [129] } \\
\hline & & Methanol & 320 ppm & & $0.56 \mathrm{~Hz} / \mathrm{ppm}$ & & \multirow{22}{*}{$\begin{array}{l}\text { Not considered } \\
\text { selective towards } \\
\text { alcohol as }\end{array}$} & \\
\hline & & Toluene & $360 \mathrm{ppm}$ & & $0.50 \mathrm{~Hz} / \mathrm{ppm}$ & & & \\
\hline & & & 262 ppm & & $0.69 \mathrm{~Hz} / \mathrm{ppm}$ & & & \\
\hline & & & $\begin{array}{l}\text { (NP diameter; } 13 \mathrm{~nm} \text {, } \\
0.4 \mathrm{mg} / \mathrm{mL} \text { ): }\end{array}$ & & & & & \\
\hline & & & 139 ppm & & $0.97 \mathrm{~Hz} / \mathrm{ppm}$ & & & \\
\hline & & & 166 ppm & & $0.81 \mathrm{~Hz} / \mathrm{ppm}$ & & & \\
\hline & & & $95 \mathrm{ppm}$ & & $1.43 \mathrm{~Hz} / \mathrm{ppm}$ & & & \\
\hline & & & $\begin{array}{l}\text { (NP diameter; } 7 \mathrm{~nm} \text {, } \\
0.4 \mathrm{mg} / \mathrm{mL} \text { ): }\end{array}$ & & & & & \\
\hline & & & $65 \mathrm{ppm}$ & & $1.63 \mathrm{~Hz} / \mathrm{ppm}$ & & & \\
\hline & & & $105 \mathrm{ppm}$ & & $1.00 \mathrm{~Hz} / \mathrm{ppm}$ & & & \\
\hline & & & $54 \mathrm{ppm}$ & & $1.94 \mathrm{~Hz} / \mathrm{ppm}$ & & & \\
\hline & & & $\begin{array}{l}\text { (NP diameter; } 50 \mathrm{~nm} \text {, } \\
0.2 \mathrm{mg} / \mathrm{mL} \text { ): }\end{array}$ & & & & & \\
\hline & & & 203 ppm & & $0.81 \mathrm{~Hz} / \mathrm{ppm}$ & & & \\
\hline & & & 311 ppm & & $0.53 \mathrm{~Hz} / \mathrm{ppm}$ & & & \\
\hline & & & $\begin{array}{l}165 \mathrm{ppm} \\
\text { (NP diameter; } 50 \mathrm{~nm} \text {, } \\
0.4 \mathrm{mg} / \mathrm{mL} \text { ): }\end{array}$ & & $1.00 \mathrm{~Hz} / \mathrm{ppm}$ & & & \\
\hline & & & $212 \mathrm{ppm}$ & & $1.06 \mathrm{~Hz} / \mathrm{ppm}$ & & & \\
\hline & & & $343 \mathrm{ppm}$ & & $0.66 \mathrm{~Hz} / \mathrm{ppm}$ & & & \\
\hline & & & 200 ppm & & $1.13 \mathrm{~Hz} / \mathrm{ppm}$ & & & \\
\hline & & & $\begin{array}{l}\text { (NP diameter; } 50 \mathrm{~nm} \text {, } \\
0.8 \mathrm{mg} / \mathrm{mL} \text { ): }\end{array}$ & & & & & \\
\hline & & & $240 \mathrm{ppm}$ & & $1.13 \mathrm{~Hz} / \mathrm{ppm}$ & & & \\
\hline & & & 309 ppm & & $0.88 \mathrm{~Hz} / \mathrm{ppm}$ & & & \\
\hline & & & 206 ppm & & $1.31 \mathrm{~Hz} / \mathrm{ppm}$ & & & \\
\hline \multirow[t]{4}{*}{$\begin{array}{l}\text { PECH and PEUT with } \\
\text { MWCNTs }\end{array}$} & \multirow[t]{4}{*}{ ST-X cut SAW } & $\begin{array}{l}\text { Octane } \\
\text { Toluene }\end{array}$ & 25 to $100 \mathrm{ppm}$ & $\sim 10$ to $100 \mathrm{~Hz}$ & $30-40 \mathrm{~s}$ response time & $\begin{array}{l}\text { Sensor sensitivity } \\
\text { favours to toluene. }\end{array}$ & \multirow[t]{4}{*}{$\begin{array}{l}\text { Least sensitive towards } \\
\text { octane }\end{array}$} & \multirow[t]{4}{*}{ [131] } \\
\hline & & & & $\sim 50$ to $450 \mathrm{~Hz}$ & & $\begin{array}{l}\text { Fast response, fast } \\
\text { recovery time and } \\
\text { good repeatability }\end{array}$ & & \\
\hline & & & $176.5 \mathrm{ppm}$ & & $\begin{array}{l}1.19 \mathrm{~Hz} / \mathrm{ppm}, 10.5 \mathrm{~s} \\
\text { response time }\end{array}$ & Low noise level for & & \\
\hline & & Ethanol & & - & (MWCNTs-PEI) & $\mathrm{SiO}_{2} / \mathrm{Si} \mathrm{NPs}$ & & \\
\hline $\begin{array}{l}\mathrm{PEI}-\mathrm{SiO}_{2} / \mathrm{Si} \mathrm{NPs} \text { and } \\
\text { MWCNTs }\end{array}$ & $\begin{array}{l}69.4 \mathrm{MHz} \text { SAW delay } \\
\text { line }\end{array}$ & & & & & & $\begin{array}{l}\text { The experiment was } \\
\text { conducted a high } \\
\text { analyte concentration } \\
1600 \mathrm{ppm}\end{array}$ & [130] \\
\hline
\end{tabular}




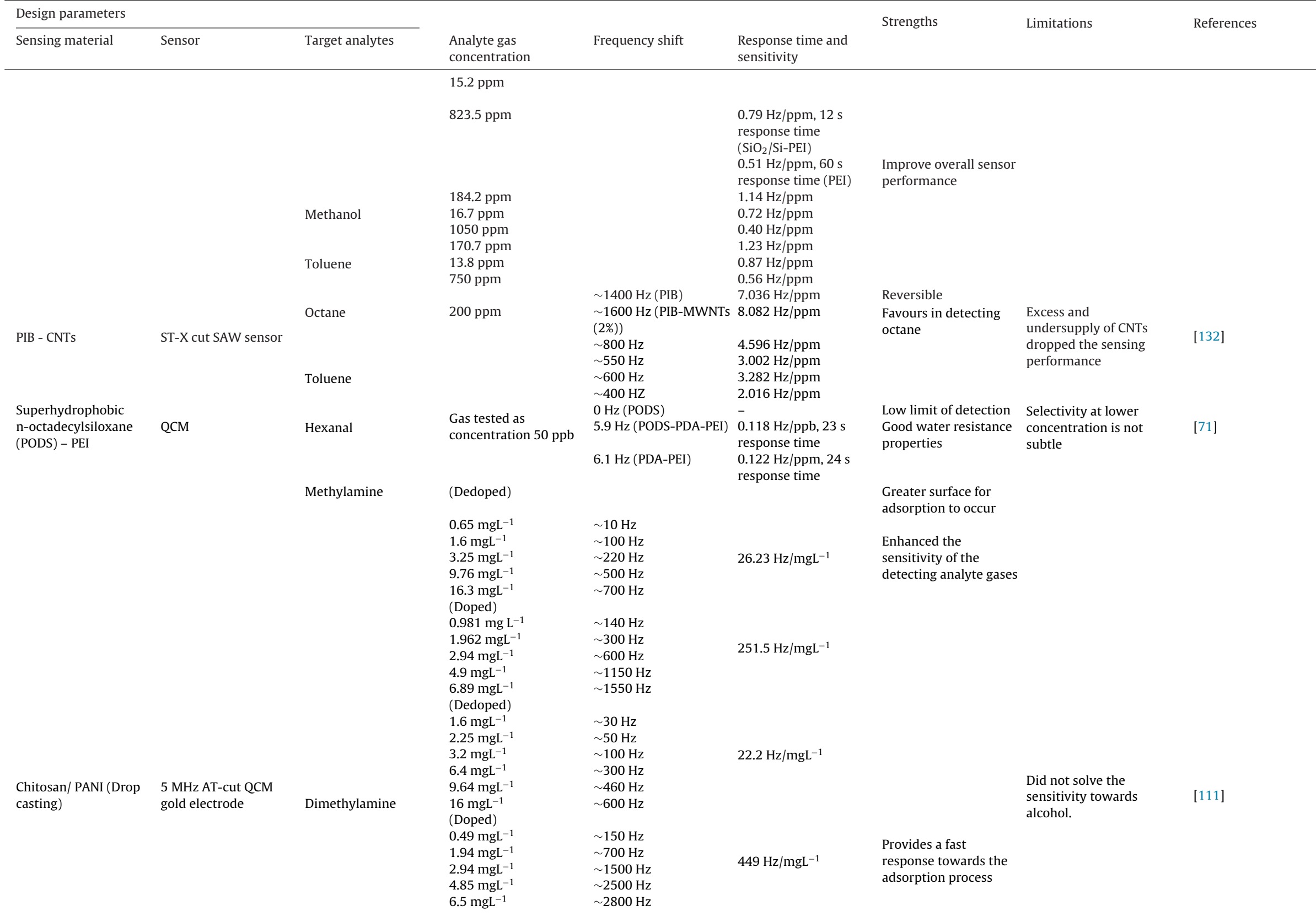




$\begin{array}{lll}\begin{array}{l}\text { Chitosan/ PEI } \\ \text { (Drop casting) }\end{array} & \begin{array}{l}5 \mathrm{MHz} \text { AT-cut QCM } \\ \text { gold electrode }\end{array} & \text { Formaldehyde }\end{array}$

\begin{tabular}{|c|c|c|}
\hline (Dedoped) & & \\
\hline $7.1 \mathrm{mg} \mathrm{L}^{-1}$ & $\sim 20 \mathrm{~Hz}$ & \\
\hline $14.2 \mathrm{mgL}^{-1}$ & $\sim 40 \mathrm{~Hz}$ & \\
\hline $21.3 \mathrm{mgL}^{-1}$ & $\sim 60 \mathrm{~Hz}$ & $3.4 \mathrm{~Hz} / \mathrm{mgL}^{-}$ \\
\hline $35.5 \mathrm{mgL}^{-1}$ & $\sim 90 \mathrm{~Hz}$ & \\
\hline $49.7 \mathrm{mgL}^{-1}$ & $\sim 120 \mathrm{~Hz}$ & \\
\hline $\begin{array}{l}71 \mathrm{mg} \mathrm{L}^{-1} \\
\text { (Doped) }\end{array}$ & $\sim 180 \mathrm{~Hz}$ & \\
\hline $10.8 \mathrm{mgL}^{-1}$ & $\sim 30 \mathrm{~Hz}$ & \\
\hline $21.6 \mathrm{mgL}^{-1}$ & $\sim 100 \mathrm{~Hz}$ & \\
\hline $32.4 \mathrm{mgL}^{-1}$ & $\sim 160 \mathrm{~Hz}$ & $8.6 \mathrm{~Hz} / \mathrm{mgL}$ \\
\hline $43.2 \mathrm{mgL}^{-1}$ & $\sim 260 \mathrm{~Hz}$ & \\
\hline $64.8 \mathrm{mgL}^{-1}$ & $\sim 470 \mathrm{~Hz}$ & \\
\hline & Chitosan, Chitosan + & \\
\hline & PEI (1500 Hz), Chitosan & \\
\hline & + PEI (8000 Hz): & \\
\hline
\end{tabular}

$85 \mathrm{ppm}$
Aids in the

interconnectivity and

surface area

Nanofibers-net-binary

NNB structure for

chitosan) for

adsorption process

Rapid response fo

analyte detection

$\begin{array}{lll}15 \mathrm{ppm} & \sim 2 \mathrm{~Hz} & \text { Rapid response for } \\ 35 \mathrm{ppm} & 2 \mathrm{~Hz}, 4 \mathrm{~Hz}, 7.5 \mathrm{~Hz} & \text { analyte detection } \\ 85 \mathrm{ppm} & 2.5 \mathrm{~Hz}, 7.5 \mathrm{~Hz}, 15 \mathrm{~Hz} & \end{array}$

$2.5 \mathrm{~Hz}, 7.5 \mathrm{~Hz}, 15 \mathrm{~Hz}$

$185 \mathrm{pp}$

MA

DMA

TMA

Graphene oxide/

chitosan

$\begin{array}{ll} & \text { DMA } \\ & \text { TMA } \\ & \text { DEA } \\ \text { 6 MHz AT-cut Ag- } & \text { TEA } \\ \text { coated QCM electrode } & \text { Ethanol } \\ & \text { Acetone } \\ & \text { Toluene }\end{array}$

5 to $150 \mathrm{ppm}$ amine

Selectivity test:

Sensitivity for amine

vapour for vapour

determination

vapour:

the structural formula Does not report the

and molecular mass effect of gas molecules

$95 \mathrm{~Hz}(\mathrm{MA})$

$2.7 \mathrm{~Hz} / \mathrm{ppm}$ (MA)

interaction with the

$2.2 \mathrm{ppm}$ (MA) $\quad 83 \mathrm{~Hz}$ (DMA) $\quad 2.3 \mathrm{~Hz} / \mathrm{ppm}$ (DMA)

Selective towards

sensing layer in terms

$2.6 \mathrm{ppm}$ (DMA) $\quad 180 \mathrm{~Hz}$ (TMA) $\quad 4.8 \mathrm{~Hz} / \mathrm{ppm}$ (TMA)

amine vapour

of the chemical groups

(ime with presponse

present involved

$\mathrm{GO}$ as it gives

greater adsorption site

Other gases:

to $50 \mathrm{ppm}<20 \mathrm{~Hz}$

selivity test

$200 \mathrm{ppm}$

$62 \mathrm{~Hz}$
$<5 \mathrm{~Hz}$

Acetic anhydride

5 ppm (LOD)

$\begin{array}{ll}10 \mathrm{MHz} \text { AT-cut QCM } & \text { Acetone } \\ \text { (OpenQCM) gold } & \text { Toluene }\end{array}$

electrode Ethanol

Methanol

Xylene

$<5 \mathrm{~Hz}$
$<5 \mathrm{~Hz}$
$<5 \mathrm{~Hz}$
$<5 \mathrm{~Hz}$
$<5 \mathrm{~Hz}$

44 s response time

Low limit of detection sensitive towards

other VOCs

$0.234 \mathrm{~Hz} / \mathrm{ppm}$ 
[112] to $3.4 \mathrm{~Hz} / \mathrm{mgL}^{-1}$ [111]. Nonetheless, functionalization of the polymer determines the target gas. Chitosan/PANI may give a frequency shift of about $20 \mathrm{~Hz}$ [111] for $7 \mathrm{mgL}^{-1}$ ethanol exposure while chitosan/PEI dropped below $5 \mathrm{~Hz}$ although exposed to a higher ethanol concentration (50 ppm) [133]. More initiative in developing biopolymer-based sensor should focus on the functionalisation of the hybrid sensing materials in accordance to the selective analyte gases. The properties of the complex biopolymer may require deeper knowledge in the physicochemical properties.

\section{Concluding remarks}

Acoustic wave sensor is surging rapidly in developing towards gas sensing application. This is due to the demanding health diagnosis issues especially in detecting cancerous diseases as most diagnosis methods are invasive, takes a long time to produce results and requires expertise to handle. Recent studies highlighted the use of breath analysis using acoustic wave sensors. Tonnes of work on acoustic wave sensors are currently progressing into producing a highly sensitive measures to cater to the limitation of current methods. The use of a sensing layer on the acoustic wave sensors determines the sensitivity and selectivity of the sensors towards the analyte gases. In our insights, metal oxide is highly sensitive towards analyte gases involving oxidation reaction. However, the concern is that most studies showed the need for high temperature to achieve the optimum sensing response. Polymers are now intensively used for sensing application. This includes the use of biopolymers. Biopolymers are showing great potential to be developed into a high selectivity and sensitivity towards the analyte gases.

However, each material that stands on its own will require modification to increase the selectivity and sensitivity of the sensor. Presently, the use of biopolymer attracts much research for this scope of the study. Fabricating biopolymer with composites allows both physicochemical and morphological modification of the sensing layer. This is a good method to increase the surface area for a greater surface for adsorption when using, for example, CNTs, and another polymer such as PANI. Modification of the sensing layer has been used using several types of materials, but there is still room for improvements. Further investigation on properties of each material and analytes gases are required for further enhance the use of acoustic wave sensor for gas sensing purposes.

\section{Declaration of Competing Interest}

The authors declare that they have no known competing financial interests or personal relationships that could have appeared to influence the work reported in this paper.

\section{Acknowledgements}

This work was fully supported by the Ministry of Higher Education (MOHE)Fundamental Research Grant Scheme (FRGS 19136-0745) (Grant No: FRGS/1/2019/TK04/UIAM/02/3).

\section{References}

[1] The Global Cancer Observatory, Malaysia - Cancer fact Sheet, World Health Organization, 2019 https://gco.iarc.fr/today/data/factsheets/populations/ 458-malaysia-fact-sheets.pdf.

[2] World Health Organisation, Latest Global Cancer Data: Cancer burden Rises to 18. 1 Million New Cases and 9. 6 Million Cancer Deaths in 2018 Latest Global Cancer Data: Cancer burden Rises to 18. 1 Million New Cases and 9. 6 Million Cancer Deaths in 2018, International Agency for Research on Cancer, 2018 https://www.iarc.fr/featured-news/latest-global-cancer-data-cancer- burden-rises-to-18-1-million-new-cases-and-9-6-million-cancer-deathsin-2018/.

[3] Y. Adiguzel, H. Kulah, Breath sensors for lung cancer diagnosis, Biosens. Bioelectron. 65 (2015) 121-138, http://dx.doi.org/10.1016/j.bios.2014.10. 023.

[4] W. Filipiak, et al., Release of volatile organic compounds (VOCs) from the lung cancer cell line CALU-1 in vitro, Cancer Cell Int. 8 (2008) 1-11, http:// dx.doi.org/10.1186/1475-2867-8-17.

[5] Q. Hua, Y. Zhu, H. Liu, Detection of volatile organic compounds in exhaled breath to screen lung cancer: a systematic review, Future Oncol. (2018), http://dx.doi.org/10.2217/fon-2017-0676.

[6] Y. Adiguzel, H. Kulah, Biosensors and bioelectronics breath sensors for lung cancer diagnosis, Biosens. Bioelectron. 65 (2015) (2014) 121-138, http://dx. doi.org/10.1016/j.bios.2014.10.023.

[7] R.G. Liteplo, R. Beauchamp, M.E. Meek, R. Chénier, Concise international chemical assessment document 40: formaldehyde, IPCS Concise Int. Chem. Assess. Doc. (40) (2002).

[8] A. Mashir, R.A. Dweik, Exhaled breath analysis: the new interface between medicine and engineering, Adv. Powder Technol. 20 (5) (2009) 420-425, http://dx.doi.org/10.1016/j.apt.2009.05.003.

[9] X. Zhang, Y. Zou, C. An, K. Ying, X. Chen, P. Wang, Sensitive detection of carcinoembryonic antigen in exhaled breath condensate using surface acoustic wave immunosensor, Sens. Actuators, B Chem. 217 (2015) 100-106, http://dx.doi.org/10.1016/j.snb.2014.10.139.

[10] M.E. Diaz, M. Debowski, C. Hukins, D. Fielding, K.M. Fong, C.S. Bettington, Non-small cell lung cancer brain metastasis screening in the era of positron emission tomography-CT staging: current practice and outcomes, J. Med. Imaging Radiat. Oncol. 62 (3) (2018) 383-388, http://dx.doi.org/10.1111/ 1754-9485.12732.

[11] H. Yu, et al., Detection volatile organic compounds in breath as markers of lung cancer using a novel electronic nose, Proc. IEEE Sens. 20031 (2) (2003) 1333-1337, http://dx.doi.org/10.1109/ICSENS.2003.1279164.

[12] G. Konvalina, H. Haick, Sensors for breath testing: from nanomaterials to comprehensive disease detection, Acc. Chem. Res. 47 (1) (2014) 66-76, http://dx.doi.org/10.1021/ar400070m.

[13] W. Li, et al., Advances in the early detection of lung cancer using analysis of volatile organic compounds: from imaging to sensors, Asian Pac. J. Cancer Prev. 15 (11) (2014) 4377-4384, http://dx.doi.org/10.7314/APJCP.2014.15. 11.4377.

[14] R. Thriumani, et al., A Study on Volatile Organic Compounds Emitted by In-vitro Lung Cancer Cultured Cells Using Gas Sensor Array and SPMEGCMS, 2018, pp. 1-17.

[15] S. Li, Y. Wan, Y. Su, C. Fan, V.R. Bhethanabotla, Gold nanoparticles amplified surface acoustic wave biosensors for immunodetection, Proc. IEEE Sens. (2017) 3-5, http://dx.doi.org/10.1109/ICSENS.2016.7808859.

[16] N. Barié, A. Voigt, M. Rapp, J. Marcoll, Fast SAW based sensor system for real-time analysis of volatile anesthetic agents, Proc. IEEE Sens. (2007) 958-961, http://dx.doi.org/10.1109/ICSENS.2007.4388562.

[17] He Shi-tang, Y. Gao, J. Shao, Y. Lu, Application of SAW gas chromatography in the early screening of lung cancer, in: 2015 Symp. Piezoelectricity, Acoust. Waves, Device Appl., 2015, pp. 22-25, http://dx.doi.org/10.1109/ SPAWDA.2015.7364432.

[18] D. Wang, Y. Wang, K. Yu, P. Wang, Systems Based on Surface Acoustic Wave Sensors for Detection of Gaseous and Liquid Exhaled Breath, 2012, pp. 317-320.

[19] A.G. Dent, T.G. Sutedja, P.V. Zimmerman, Exhaled breath analysis for lung cancer, J. Thorac. Dis. 5 (SUPPL.5) (2013), http://dx.doi.org/10.3978/j.issn. 2072-1439.2013.08.44.

[20] N. Queralto, A.N. Berliner, B. Goldsmith, R. Martino, P. Rhodes, S.H. Lim, Detecting cancer by breath volatile organic compound analysis: a review of array-based sensors, J. Breath Res. 8 (2) (2014) 027112, http://dx.doi.org/10. 1088/1752-7155/8/2/027112.

[21] C. Di Natale, et al., Lung cancer identification by the analysis of breath by means of an array of non-selective gas sensors, Biosens. Bioelectron. 18 (10) (2003) 1209-1218, http://dx.doi.org/10.1016/S0956-5663(03)00086-1.

[22] X. Sun, K. Shao, T. Wang, Detection of volatile organic compounds (VOCs) from exhaled breath as noninvasive methods for cancer diagnosis, Anal. Bioanal. Chem. 408 (11) (2016) 2759-2780, http://dx.doi.org/10.1007/ s00216-015-9200-6.

[23] M. Righettoni, A. Amann, S.E. Pratsinis, Breath analysis by nanostructured metal oxides as chemo-resistive gas sensors, Mater. Today 18 (3) (2015) 163-171, http://dx.doi.org/10.1016/j.mattod.2014.08.017.

[24] J. Guo, J. Zhang, H. Gong, D. Ju, B. Cao, Au nanoparticle-functionalized 3D SnO2microstructures for high performance gas sensor, Sens. Actuators, B Chem. 226 (2016) 266-272, http://dx.doi.org/10.1016/j.snb.2015.11.140.

[25] R.D.S. Yadava, V.K. Verma, A diffusion limited sorption-desorption noise model for polymer coated SAW chemical sensors, Sens. Actuators, B Chem. 195 (2014) 590-602, http://dx.doi.org/10.1016/j.snb.2014.01.067.

[26] H. Haick, S. Cohen-Kaminsky, Detecting lung infections in breathprints: empty promise or next generation diagnosis of infections, Eur. Respir. J. 45 (1) (2015) 21-24, http://dx.doi.org/10.1183/09031936.00183714.

[27] H. Kida, Exhaled breath analysis for lung cancer, Seimitsu Kogaku Kaishi/J. Jpn. Soc. Precis. Eng. (2016), http://dx.doi.org/10.2493/jjspe.82.718.

[28] M. P.J, Analysis of volatile organic compounds in the exhaled breath for the diagnosis of lung cancer, J. Thorac. Oncol. 3 (7) (2008) 774-780 [Online]. 
Available: http://ovidsp.ovid.com/ovidweb. cgi?T=JS\&PAGE=reference \&D=emed8\&NEWS=N\&AN=2009365661.

[29] A. Amann, et al., The human volatilome: volatile organic compounds (VOCs) in exhaled breath, skin emanations, urine, feces and saliva, J. Breath Res. 8 (3) (2014), http://dx.doi.org/10.1088/1752-7155/8/3/034001.

[30] H. Haick, Y.Y. Broza, P. Mochalski, V. Ruzsanyi, A. Amann, Assessment, origin, and implementation of breath volatile cancer markers, Chem. Soc. Rev. 43 (5) (2014) 1423-1449, http://dx.doi.org/10.1039/c3cs60329f.

[31] O. Barash, U. Tisch, H. Haick, Volatile organic compounds and the potential for a lung cancer breath test, Lung Cancer Manag. 2 (6) (2013) 471-482, http://dx.doi.org/10.2217/lmt.13.58.

[32] N. Van Regenmortel, M. Malbrain, P. Jorens, To the editor, N. Engl. J. Med. 372 (4) (2015) 390, http://dx.doi.org/10.1056/NEJMc1414731.

[33] Y.J. Lee, et al., The association between alcohol metabolism and genetic variants of ADH1A, SRPRB, and PGM1 in Korea, Alcohol 79 (2019) 137-145, http://dx.doi.org/10.1016/j.alcohol.2019.03.004.

[34] B.L. McVicker, D.J. Tuma, A.A. Naji, C.A. Casey, Alcohol and Apoptosis, vol. 3-3, Elsevier Ltd, 2005

[35] K.O. Alfarouk, et al., Glycolysis, tumor metabolism, cancer growth and dissemination. A new pH-based etiopathogenic perspective and therapeutic approach to an old cancer question, Oncoscience 1 (12) (2014) 777-802, http://dx.doi.org/10.18632/oncoscience.109.

[36] M.V. Liberti, J.W. Locasale, The warburg effect: how does it benefit Cancer cells? (vol 41, pg 211, 2016), Trends Biochem. Sci. 41 (3) (2016) 287, http:// dx.doi.org/10.1016/j.tibs.2016.01.004, SI.

[37] W. Zhang, S.L. Zhang, X. Hu, K.Y. Tam, Targeting tumor metabolism for cancer treatment: is pyruvate dehydrogenase kinases (PDKs) a viable anticancer target? Int. J. Biol. Sci. 11 (12) (2015) 1390-1400, http://dx.doi. org/10.7150/ijbs.13325.

[38] Z. Jia, A. Patra, V.K. Kutty, T. Venkatesan, Critical review of volatile organic compound analysis in breath and in vitro cell culture for detection of lung cancer, Metabolites 9 (3) (2019), http://dx.doi.org/10.3390/metabo9030052.

[39] R. Capuano, A. Catini, R. Paolesse, C. Di Natale, Sensors for lung Cancer diagnosis, J. Clin. Med. 8 (2) (2019) 235, http://dx.doi.org/10.3390/ jcm8020235.

[40] C. Di Natale, R. Paolesse, A. D’Amico, Metalloporphyrins based artificial olfactory receptors, Sens. Actuators, B Chem. 121 (1) (2007) 238-246, http:// dx.doi.org/10.1016/j.snb.2006.09.038.

[41] M. Hakim, et al., Volatile organic compounds of lung Cancer and possible biochemical pathways, Chem. Rev. 112 (11) (2012) 5949-5966, http://dx. doi.org/10.1021/cr300174a.

[42] E.-E. Chang, et al., Analysis of volatile organic compounds in exhaled breath for lung cancer diagnosis using a sensor system, Sens. Actuators B. Chem. 255 (2018) (2018) 800-807, http://dx.doi.org/10.1016/j.snb.2017.08.057.

[43] L. Wang, J. Gao, J. Xu, QCM formaldehyde sensing materials: design and sensing mechanism, Sens. Actuators, B Chem. 293 (March) (2019) 71-82, http://dx.doi.org/10.1016/j.snb.2019.04.050.

[44] M.M. Ayad, N.L. Torad, Alcohol vapours sensor based on thin polyaniline salt film and quartz crystal microbalance, Talanta 78 (4-5) (2009) 1280-1285, http://dx.doi.org/10.1016/j.talanta.2009.01.053.

[45] A. Afzal, N. Iqbal, A. Mujahid, R. Schirhagl, Advanced vapor recognition materials for selective and fast responsive surface acoustic wave sensors: a review, Anal. Chim. Acta 787 (2013) 36-49, http://dx.doi.org/10.1016/j.aca. 2013.05.005.

[46] J.J. Cai, H.X. Chen, Y.L. Guan, S.W. Chou, E.S. Jeng, Study on the polymer-coated surface acoustic wave sensors for organic vapor detection, ISNE 2016, in: 2016 5th Int. Symp. Next-Generation Electron., vol. 2, 2016, pp. 1-2, http://dx.doi.org/10.1109/ISNE.2016.7543338.

[47] M.M. Ayad, N. Salahuddin, I.M. Minisy, Detection of some volatile organic compounds with chitosan-coated quartz crystal microbalance, Des. Monomers Polym. 17 (8) (2014) 795-802, http://dx.doi.org/10.1080/ 15685551.2014 .918019

[48] J.C. Chiou, C.C. Wu, A wearable and wireless gas-sensing system using flexible polymer/multi-walled carbon nanotube composite films, Polymers (Basel) 9 (9) (2017), http://dx.doi.org/10.3390/polym9090457.

[49] L. Kosuru, A. Bouchaala, N. Jaber, M.I. Younis, Humidity detection using metal organic framework coated on QCM, J. Sensors 2016 (2016), http://dx. doi.org/10.1155/2016/4902790.

[50] N. Wang, X. Wang, Y. Jia, X. Li, J. Yu, B. Ding, Electrospun nanofibrous chitosan membranes modified with polyethyleneimine for formaldehyde detection, Carbohydr. Polym. 108 (1) (2014) 192-199, http://dx.doi.org/10. 1016/j.carbpol.2014.02.088.

[51] X. Yang, et al., Fabrication of highly sensitive gas sensor based on Au functionalized WO3 composite nanofibers by electrospinning, Sens. Actuators, B Chem. 220 (2015) 1112-1119, http://dx.doi.org/10.1016/j.snb. 2015.05.121.

[52] S. Liu, et al., Dynamic chemical vapor sensing with nanofibrous film based surface acoustic wave sensors, Sens. Actuators, A Phys. 167 (1) (2011) 8-13, http://dx.doi.org/10.1016/j.sna.2011.02.007.

[53] P.G. Su, Y.S. Chuang, Flexible H2 sensors fabricated by layer-by-layer self-assembly thin film of multi-walled carbon nanotubes and modified in situ with Pd nanoparticles, Sens. Actuators, B Chem. 145 (1) (2010) 521-526, http://dx.doi.org/10.1016/j.snb.2009.12.068.

[54] Y. Ogimoto, R. Selyanchyn, N. Takahara, S. Wakamatsu, S.W. Lee, Detection of ammonia in human breath using quartz crystal microbalance sensors with functionalized mesoporous SiO2 nanoparticle films, Sens. Actuators, B Chem. 215 (2015) 428-436, http://dx.doi.org/10.1016/j.snb.2015.03.103.

[55] F. Ritter, et al., Polymer structures on surface acoustic wave biosensors, Procedia Technol. 27 (2017) 35-36, http://dx.doi.org/10.1016/j.protcy.2017. 04.017

[56] M. García, et al., Differentiation of red wines using an electronic nose based on surface acoustic wave devices, Talanta 68 (4) (2006) 1162-1165, http:// dx.doi.org/10.1016/j.talanta.2005.07.031.

[57] E.M. Dahmane, M. Taourirte, N. Eladlani, M. Rhazi, Extraction and characterization of chitin and chitosan from Parapenaeus longirostris from moroccan local sources, Int. J. Polym. Anal. Charact. 19 (4) (2014) 342-351, http://dx.doi.org/10.1080/1023666X.2014.902577.

[58] L. Rana, R. Gupta, M. Tomar, V. Gupta, ZnO/ST-Quartz SAW resonator: an efficient NO 2 gas sensor, Sens. Actuators, B Chem. 252 (2) (2017) 840-845, http://dx.doi.org/10.1016/j.snb.2017.06.075.

[59] A. Afzal, N. Cioffi, L. Sabbatini, L. Torsi, NO x sensors based on semiconducting metal oxide nanostructures: progress and perspectives, Sens. Actuators, B Chem 171-172 (2012) (2012) 25-42, http://dx.doi.org/10. 1016/j.snb.2012.05.026

[60] A. Mirzaei, S.G. Leonardi, G. Neri, Detection of hazardous volatile organic compounds (VOCs) by metal oxide nanostructures-based gas sensors: a review, Ceram. Int. 42 (14) (2016) 15119-15141, http://dx.doi.org/10.1016/ j.ceramint.2016.06.145.

[61] M.C. Horrillo, et al., Optimization of SAW sensors with a structure $\mathrm{ZnO}-\mathrm{SiO} 2$ Si to detect volatile organic compounds, Sens. Actuators, B Chem 118 (1-2) (2006) 356-361, http://dx.doi.org/10.1016/j.snb.2006.04.050.

[62] P.G. Su, et al., A study of an electronic nose for detection of lung cancer based on a virtual SAW gas sensors array and imaging recognition method, Sens. Actuators, B Chem. 2 (1) (2017) 1535-1546, http://dx.doi.org/10.1088 0957-0233/16/8/001.

[63] M.J. Abdullah, A.A. Aziz, H. Ahmad, L.Y. Low, ZnO thin films for VOC sensing applications, Vacuum 85 (2010) (2010) 101-106, http://dx.doi.org/10.1016/ j.vacuum.2010.04.009.

[64] I.V. Zaporotskova, N.P. Boroznina, Y.N. Parkhomenko, L.V. Kozhitov, Carbon nanotubes: sensor properties. A review, Mod. Electron. Mater. 2 (4) (2016) 95-105, http://dx.doi.org/10.1016/j.moem.2017.02.002.

[65] Z. Xiao, et al., Recent development in nanocarbon materials for gas sensor applications, Sens. Actuators, B Chem 274 (July) (2018) 235-267, http://dx. doi.org/10.1016/j.snb.2018.07.040.

[66] I. Sayago, et al., Graphene oxide as sensitive layer in Love-wave surface acoustic wave sensors for the detection of chemical warfare agent simulants, Talanta 148 (2016) 393-400, http://dx.doi.org/10.1016/j.talanta. 2015.10.069.

[67] M. Castro, B. Kumar, J.F. Feller, Z. Haddi, A. Amari, B. Bouchikhi, Novel e-nose for the discrimination of volatile organic biomarkers with an array of carbon nanotubes (CNT) conductive polymer nanocomposites (CPC) sensors, Sens. Actuators, B Chem. 159 (1) (2011) 213-219, http://dx.doi.org/10.1016/j.snb. 2011.06.073.

[68] V. Kumar, P.K. Tyagi, Potential application of multi-walled carbon nanotubes/activated carbon/bamboo charcoal for efficient alcohol sensing, J. Alloys Compd. 767 (2018) 215-222, http://dx.doi.org/10.1016/j.jallcom. 2018.06.123.

[69] T. Yang, Z. Li, Y. Dong, X. Wang, Gas sensor array based on multi-walled carbon nanotubes and polymer, Iceep, in: Adv. Eng. Res. 7th Int. Conf. Energy Environ. Prot. (ICEEP 2018), vol. 170, 2018, pp. 1790-1796, http://dx. doi.org/10.2991/iceep-18.2018.325.

[70] X. Du, Z. Ying, Y. Jiang, Z. Liu, T. Yang, G. Xie, Synthesis and evaluation of a new polysiloxane as SAW sensor coatings for DMMP detection, Sens. Actuators, B Chem. 134 (2) (2008) 409-413, http://dx.doi.org/10.1016/j.snb. 2008.05.016.

[71] L. Wang, Y. Wu, G. Li, H. Xu, J. Gao, Q. Zhang, Superhydrophobic n-octadecylsiloxane (PODS)-functionalized PDA-PEI film as efficient water-resistant sensor for ppb-level hexanal detection, Chem. Eng. J. 399 (June) (2020) 125755, http://dx.doi.org/10.1016/j.cej.2020.125755.

[72] L. Wang, Metal-organic frameworks for QCM-based gas sensors: a review, Sens. Actuators, A Phys. 307 (2020) 111984, http://dx.doi.org/10.1016/j.sna. 2020.111984.

[73] A.H. Khoshaman, B. Bahreyni, Application of metal organic framework crystals for sensing of volatile organic gases, Proc. IEEE Sens. (2011) 1101-1104, http://dx.doi.org/10.1109/ICSENS.2011.6127386.

[74] P. Verma, R.D.S. Yadava, Polymer selection for SAW sensor array based electronic noses by fuzzy c-means clustering of partition coefficients: model studies on detection of freshness and spoilage of milk and fish, Sens. Actuators, B Chem. 209 (2015) 751-769, http://dx.doi.org/10.1016/j.snb. 2014.11.149.

[75] M. Penza, P. Aversa, G. Cassano, W. Wlodarski, K. Kalantar-Zadeh, Layered SAW gas sensor with single-walled carbon nanotube-based nanocomposite coating, Sens. Actuators, B Chem. 127 (1) (2007) 168-178, http://dx.doi.org/ 10.1016/j.snb.2007.07.028.

[76] J. Xie, H. Wang, Y. Lin, Y. Zhou, Y. Wu, Highly sensitive humidity sensor based on quartz crystal microbalance coated with $\mathrm{ZnO}$ colloid spheres, Sens. Actuators, B Chem. 177 (2013) 1083-1088, http://dx.doi.org/10.1016/j.snb. 2012.12.033.

[77] Y. Masuda, T. Itoh, W. Shin, K. Kato, SnO2 nanosheet/nanoparticle detector for the sensing of 1-nonanal gas produced by lung cancer, Sci. Rep. 5 (December 2014) (2015) 1-7, http://dx.doi.org/10.1038/srep10122. 
[78] Y. Masuda, K. Kato, M. Kida, J. Otsuka, Selective nonanal molecular recognition with SnO2 nanosheets for lung cancer sensor, Int. J. Appl. Ceram. Technol. (November) (2019) 1807-1811, http://dx.doi.org/10.1111/ijac. 13154.

[79] Y. Zhu, J. Chen, H. Li, Y. Zhu, J. Xu, Synthesis of mesoporous SnO2-SiO2 composites and their application as quartz crystal microbalance humidity sensor, Sens. Actuators, B Chem. 193 (2014) 320-325, http://dx.doi.org/10. 1016/j.snb.2013.11.091.

[80] Z. Wen, L. Tian-mo, Gas-sensing properties of SnO 2 - TiO 2 -based sensor for volatile organic compound gas and its sensing mechanism, Phys. B Phys. Condens. Matter 405 (5) (2010) 1345-1348, http://dx.doi.org/10.1016/j. physb.2009.11.086.

[81] G. Wu, et al., Hierarchical structured TiO 2 nano-tubes for formaldehyde sensing, Ceram. Int. 38 (8) (2012) 6341-6347, http://dx.doi.org/10.1016/j ceramint.2012.05.004

[82] U. Stahl, et al., Long-term stability of polymer-coated surface transversewave sensors for the detection of organic solvent vapors, Sensors (Switzerland) 17 (11) (2017), http://dx.doi.org/10.3390/s17112529.

[83] J.P. Santos, et al., SAW sensor array for wine discrimination, Sens. Actuators B Chem 107 (1) (2005) 291-295, http://dx.doi.org/10.1016/j.snb.2004.10. 013, SPEC. ISS.

[84] X. Chen, et al., A study of an electronic nose for detection of lung cancer based on a virtual SAW gas sensors array and imaging recognition method, Meas. Sci. Technol. 16 (8) (2005) 1535-1546, http://dx.doi.org/10.1088/ 0957-0233/16/8/001.

[85] F. Razan, C. Zimmermann, D. Rebiere, C. Dejous, J. Pistre, Response of polymer-coated love-wave device: A method to characterize thin film in the radio frequency domain, IEEE Int. Symp. Ind. Electron. 1 (2004) 37-41, http://dx.doi.org/10.1109/ISIE.2004.1571778.

[86] P. Singh, R.D.S. Yadava, Feature extraction by wavelet decomposition of surface acoustic wave sensor array transients, Def. Sci. J. 60 (4) (2010) $377-386$

[87] M. Kimura, Y. Liu, R. Sakai, S. Sato, Detection of volatile organic compounds by analyses of polymer-coated quartz crystal microbalance sensor arrays, Sens. Mater 23 (7) (2011) 359, http://dx.doi.org/10.18494/sam.2011.743.

[88] W. Chen, Z. Wang, S. Gu, J. Wang, Detection of hexanal in humid circumstances using hydrophobic molecularly imprinted polymers composite, Sens. Actuators, B Chem 291 (January) (2019) 141-147, http:// dx.doi.org/10.1016/j.snb.2019.04.065.

[89] M. Bhattacharyya Banerjee, et al., Detection of benzene and volatile aromatic compounds by molecularly imprinted polymer-coated quartz crystal microbalance sensor, IEEE Sens. J. 19 (3) (2019) 885-892, http://dx. doi.org/10.1109/JSEN.2018.2878926.

[90] M.M. Ayad, G. El-Hefnawey, N.L. Torad, A sensor of alcohol vapours based on thin polyaniline base film and quartz crystal microbalance, J. Hazard. Mater. 168 (1) (2009) 85-88, http://dx.doi.org/10.1016/j.jhazmat.2009.02.003.

[91] S. T, S.P.S. Sneha Mohan, Oluwatobi S. Oluwafemi, Nandakumar Kalarikkal, Biopolymers - application in nanoscience and nanotechnology, Recent Adv. Biopolym. (2016) 47-72, http://dx.doi.org/10.5772/62225.

[92] F. Usman, et al., Results in physics synthesis and characterisation of a ternary composite of polyaniline, reduced graphene-oxide and chitosan with reduced optical band gap and stable aqueous dispersibility, Results Phys. 15 (July) (2019) 102690, http://dx.doi.org/10.1016/j.rinp.2019.102690.

[93] R.T. De Silva, P. Pasbakhsh, K.L. Goh, S. Chai, H. Ismail, Physico-chemical characterisation of chitosan/halloysite composite membranes, Polym. Test. 32 (2) (2013) 265-271, http://dx.doi.org/10.1016/j.polymertesting.2012.11. 006

[94] I.F.M. Rumengan, E. Suryanto, R. Modaso, S. Wullur, T.E. Tallei, D. Limbong, Structural characteristics of chitin and chitosan isolated from the biomass of cultivated rotifer, Brachionus rotundiformis, Int. J. Fish. Aquat. Sci. 3 (1) (2014) 12-18

[95] O.A. Olafadehan, O.Y. Akpo, O. Enemuo, K.O. Amoo, O.G. Abatan, Equilibrium, kinetic and thermodynamic studies of biosorption of zinc ions from industrial wastewater using derived composite biosorbents from walnut shell, Afr. J. Environ. Sci. Technol. 12 (9) (2018) 335-356, http://dx.doi.org/ 10.5897/ajest2018.2515.

[96] T. Cheng, R.D. Hund, D. Aibibu, J. Horakova, C. Cherif, Pure chitosan and chitsoan/chitosan lactate blended nanofibres made by single step electrospinning, Autex Res. J. 13 (4) (2013) 128-133, http://dx.doi.org/10. 2478/v10304-012-0040-6.

[97] A. Aljawish, I. Chevalot, J. Jasniewski, J. Scher, L. Muniglia, Enzymatic synthesis of chitosan derivatives and their potential applications, J. Mol Catal. B Enzym. 112 (February) (2015) 25-39, http://dx.doi.org/10.1016/j. molcatb.2014.10.014.

[98] S.S. Silva, R.L. Reis, Morphology and Miscibility of Chitosan/Soy Protein Blended Membranes, vol. 70, 2007, pp. 25-31, http://dx.doi.org/10.1016/j. carbpol.2007.02.023.

[99] J. Zhang, et al., Chitosan modification and pharmaceutical/biomedical applications, Mar. Drugs 8 (7) (2010) 1962-1987, http://dx.doi.org/10.3390/ md8071962.

[100] P. Negrea, A. Caunii, I. Sarac, M. Butnariu, The study of infrared spectrum of chitin and chitosan extract as potential sources of biomass, Dig. J. Nanomater. Biostruct. 10 (4) (2015) 1129-1138.
[101] J. Menegotto, F. Pavoni, C.L. Luchese, I.C. Tessaro, Impact of acid type for chitosan dissolution on the characteristics and biodegradability of cornstarch/chitosan based fi lms, Int. J. Biol. Macromol. 138 (2019) 693-703. http://dx.doi.org/10.1016/j.ijbiomac.2019.07.089.

[102] C.R. Afonso, et al., Biodegradable antioxidant chitosan fi lms useful as an anti-aging skin mask, Int. J. Biol. Macromol. 132 (2019) 1262-1273, http:// dx.doi.org/10.1016/j.ijbiomac.2019.04.052.

[103] V. Nayak, M.S. Jyothi, R.G. Balakrishna, M. Padaki, A.F. Ismail, Preparation and characterization of chitosan thin films on mixed-matrix membranes for complete removal of chromium, ChemistryOpen 4 (3) (2015) 278-287, http://dx.doi.org/10.1002/open.201402133.

[104] S. Bhuvaneshwari*, D. Sruthi*, V. Sivasubramanian*, Niranjana kalyani**, J. Sugunabai **, Development and characterization of chitosan film, Int. J. Eng. Res. Appl. 1 (2) (2011) 292-299 [Online]. Available: http://www.ijera.com/papers/vol1issue 2/012292299AL.pdf.

[105] Y.X. Xu, K.M. Kim, M.A. Hanna, D. Nag, Chitosan-starch composite film: preparation and characterization, Ind. Crops Prod. 21 (2) (2005) 185-192, http://dx.doi.org/10.1016/j.indcrop.2004.03.002.

[106] I. Arzate-vázquez, et al., Microstructural Characterization of Chitosan and Alginate Films by Microscopy Techniques and Texture Image Analysis, 87, 2012, pp. 289-299, http://dx.doi.org/10.1016/j.carbpol.2011.07.044.

[107] K. Sivaselvi, P. Ghosh, Sciencedirect characterization of modified Chitosan thin film, Mater. Today Proc. 4 (2) (2017) 442-451, http://dx.doi.org/10. 1016/j.matpr.2017.01.043.

[108] M. Taheri, M. Ghiaci, A. Shchukarev, Cross-linked chitosan with a dicationic ionic liquid as a recyclable biopolymer-supported catalyst for cycloaddition of carbon dioxide with epoxides into cyclic carbonates, New J. Chem. 42 (1) (2018) 587-597, http://dx.doi.org/10.1039/c7nj03665e.

[109] E. Praveen, S. Murugan, K. Jayakumar, Investigations on the existence of piezoelectric property of a bio-polymer-chitosan and its application in vibration sensors, RSC Adv. 7 (56) (2017) 35490-35495, http://dx.doi.org/ 10.1039/c7ra04752e.

[110] A.K. Havare, H. Ilgu, S. Okur, G. Sanl-Mohamed, Humidity sensing properties of chitosan by using quartz crystal microbalance method, Sens. Lett. 10 (3-4) (2012) 906-910, http://dx.doi.org/10.1166/sl.2012.2585.

[111] M.M. Ayad, N.A. Salahuddin, I.M. Minisy, W.A. Amer, Chitosan/polyaniline nanofibers coating on the quartz crystal microbalance electrode for gas sensing, Sens. Actuators, B Chem. 202 (2014) 144-153, http://dx.doi.org/10. 1016/j.snb.2014.05.046.

[112] K. Triyana, et al., Chitosan-based quartz crystal microbalance for alcohol sensing, Electronics 7 (9) (2018) 181, http://dx.doi.org/10.3390/ electronics7090181.

[113] N. Athirah Awatif Abdul Rahman, A. Hadi Ma'Radzi, A. Zakaria, Fabrication of quartz crystal microbalance with pegylated lipopolymer for detection of non-invasive lung cancer biomarker, Mater. Today Proc. 7 (2019) 632-637, http://dx.doi.org/10.1016/j.matpr.2018.12.054.

[114] N.A.A.A. Rahman, A.H. Ma'Radzi, A. Zakaria, Determination of non-invasive lung Cancer biomarker by quartz crystal microbalance coated with pegylated lipopolymer, IOP Conf. Ser. Mater. Sci. Eng. 458 (1) (2018), http:// dx.doi.org/10.1088/1757-899X/458/1/012020.

[115] M. Penza, M.A. Tagliente, P. Aversa, G. Cassano, L. Capodieci, Single-walled carbon nanotubes nanocomposite microacoustic organic vapor sensors, Mater. Sci. Eng. C 26 (5-7) (2006) 1165-1170, http://dx.doi.org/10.1016/j. msec.2005.09.059.

[116] D.R. Kauffman, A. Star, Carbon nanotube gas and vapor sensors, Angew. Chemie - Int. Ed. 47 (35) (2008) 6550-6570, http://dx.doi.org/10.1002/anie. 200704488

[117] W. De Zhang, W.H. Zhang, Carbon nanotubes as active components for gas sensors, J. Sens. 2009 (2009), http://dx.doi.org/10.1155/2009/160698.

[118] M. Penza, F. Antolini, M. Vittori-antisari, Carbon nanotubes-based surface acoustic waves oscillating sensor for vapour detection, Thin Solid Films 472 (2005) (2005) 246-252, http://dx.doi.org/10.1016/j.tsf.2004.07.071.

[119] M. Penza, F. Antolini, M.V. Antisari, Carbon nanotubes as SAW chemical sensors materials, Sens. Actuators, B Chem. 100 (2004) (2004) 47-59, http:// dx.doi.org/10.1016/j.snb.2003.12.019.

[120] T. Helbling, et al., Sensing NO2 with individual suspended single-walled carbon nanotubes, Sens. Actuators, B Chem. 132 (2) (2008) 491-497, http:// dx.doi.org/10.1016/j.snb.2007.11.036.

[121] P. Slobodian, P. Riha, A. Lengalova, P. Svoboda, P. Saha, Multi-wall carbon nanotube networks as potential resistive gas sensors for organic vapor detection, Carbon N.Y. 49 (7) (2011) 2499-2507, http://dx.doi.org/10.1016/j. carbon.2011.02.020.

[122] I. Hafaiedh, W. El Euch, P. Clement, E. Llobet, A. Abdelghani, Multi-walled carbon nanotubes for volatile organic compound detection, Sens. Actuators, B Chem. 182 (2013) 344-350, http://dx.doi.org/10.1016/j.snb.2013.03.020.

[123] I. Sayago, et al., Carbon nanotube-based SAW sensors, Proc. 2013 Spanish Conf. Electron Devices, CDE 2013 (2013) 127-130, http://dx.doi.org/10. 1109/CDE.2013.6481359, no. Table 1.

[124] M. Consales, et al., Carbon nanotubes thin films fiber optic and acoustic VOCs sensors: performances analysis, Sens. Actuators, B Chem. 118 (1-2) (2006) 232-242, http://dx.doi.org/10.1016/j.snb.2006.04.028.

[125] A. Ghosh, C. Zhang, S. Shi, H. Zhang, High temperature CO2 sensing and its cross-sensitivity towards $\mathrm{H} 2$ and $\mathrm{CO}$ gas using calcium doped $\mathrm{ZnO}$ thin film 
coated langasite SAW sensor, Sens. Actuators B Chem 301 (April) (2019) 126958, http://dx.doi.org/10.1016/j.snb.2019.126958.

[126] G. Lal, D.C. Tiwari, Investigation of nanoclay doped polymeric composites on piezoelectric Quartz Crystal Microbalance (QCM) sensor, Sens. Actuators, B Chem. 262 (2018) 64-69, http://dx.doi.org/10.1016/j.snb.2018.01.200.

[127] X. Ma, B. Zhang, Q. Cong, X. He, M. Gao, G. Li, Organic/inorganic nanocomposites of $\mathrm{ZnO} / \mathrm{CuO} /$ chitosan with improved properties, Mater Chem. Phys. 178 (2016) 88-97, http://dx.doi.org/10.1016/j.matchemphys. 2016.04.074.

[128] J. Wang, L. Liu, S.Y. Cong, J.Q. Qi, B.K. Xu, An enrichment method to detect low concentration formaldehyde, Sens. Actuators, B Chem. 134 (2) (2008) 1010-1015, http://dx.doi.org/10.1016/j.snb.2008.07.010.

[129] C. Viespe, D. Miu, Characteristics of surface acoustic wave sensors with nanoparticles embedded in polymer sensitive layers for VOC detection, Sensors (Switzerland) 18 (7) (2018), http://dx.doi.org/10.3390/s18072401.

[130] C. Viespe, C. Grigoriu, Surface acoustic wave sensors with carbon nanotubes and $\mathrm{SiO} 2 / \mathrm{Si}$ nanoparticles based nanocomposites for VOC detection, Sens. Actuators, B Chem. 147 (1) (2010) 43-47, http://dx.doi.org/10.1016/j.snb. 2010.02.064.

[131] I. Sayago, et al., New sensitive layers for surface acoustic wave gas sensors based on polymer and carbon nanotube composites, Sens. Actuators, B Chem. 175 (2012) 67-72, http://dx.doi.org/10.1016/j.snb.2011.12.031.

[132] I. Sayago, et al., Surface acoustic wave gas sensors based on polyisobutylene and carbon nanotube composites, Sens. Actuators, B Chem. 156 (1) (2011) 1-5, http://dx.doi.org/10.1016/j.snb.2011.04.047.

[133] K. Zhang, R. Hu, G. Fan, G. Li, Graphene oxide/chitosan nanocomposite coated quartz crystal microbalance sensor for detection of amine vapors, Sens. Actuators, B Chem. 243 (2017) 721-730, http://dx.doi.org/10.1016/j. snb.2016.12.063.

[134] M. Penza, M.A. Tagliente, P. Aversa, G. Cassano, Organic-vapor detection using carbon-nanotubes nanocomposite microacoustic sensors, Chem. Phys. Lett. 409 (4-6) (2005) 349-354, http://dx.doi.org/10.1016/j.cplett.2005.05. 005.

[135] Y. Chen, C. Zhu, T. Wang, The enhanced ethanol sensing properties of multi-walled carbon nanotubes/SnO2 core/shell nanostructures, Nanotechnology 17 (12) (2006) 3012-3017, http://dx.doi.org/10.1088/ 0957-4484/17/12/033.

[136] M. David, M. Arab, C. Martino, L. Delmas, F. Guinneton, J. Gavarri, Carbon nanotubes / ceria composite layers deposited on surface acoustic wave devices for gas detection at room temperature, Thin Solid Films 520 (14) (2012) 4786-4791, http://dx.doi.org/10.1016/j.tsf.2011.10.166.

[137] Y. Zhou, Y. Jiang, G. Xie, X. Du, H. Tai, Gas sensors based on multiple-walled carbon nanotubes-polyethylene oxide films for toluene vapor detection, Sens. Actuators, B Chem. 191 (November 2017) (2014) 24-30, http://dx.doi org/10.1016/j.snb.2013.09.079.

[138] D.B. Nugroho, A. Rianjanu, K. Triyana, A. Kusumaatmaja, R. Roto, Quartz crystal microbalance-coated cellulose acetate nanofibers overlaid with chitosan for detection of acetic anhydride vapor, Results Phys. (2019) 102680, http://dx.doi.org/10.1016/j.rinp.2019.102680.

[140] A.T. Lawal, G.G. Wallace, Vapour phase polymerisation of conducting and non-conducting polymers: a review, Talanta 119 (2014) 133-143, http://dx doi.org/10.1016/j.talanta.2013.10.023.

[141] P.F. Crucitti, F. Longo, R. Rocco, G. Rocco, e-Nose Technology: the State of the Art on Lung Cancer Diagnosis, Elsevier Inc., 2018.

[142] S. Sivaramakrishnan, R. Rajamani, C.S. Smith, K.A. McGee, K.R. Mann, N. Yamashita, Carbon nanotube-coated surface acoustic wave sensor for carbon dioxide sensing, Sens. Actuators, B Chem. 132 (1) (2008) 296-304 http://dx.doi.org/10.1016/j.snb.2008.01.041.

[143] P. Qi, O. Vermesh, M. Grecu, A. Javey, Q. Wang, H. Dai, Toward large arrays of multiplex functionalized carbon nanotube sensors for highly sensitive and selective molecular detection, Nano Lett. 3 (3) (2003) 347-351, http://dx. doi.org/10.1021/nl034010k.

[144] T. Zhang, M.B. Nix, B.-Y. Yoo, M.A. Deshusses, N.V. Myung, Electrochemically functionalized single-walled carbon nanotube gas sensor, Electronalysis 18 (12) (2006) 1153-1158, http://dx.doi.org/10.1002/elan.200603527.

\section{Biographies}

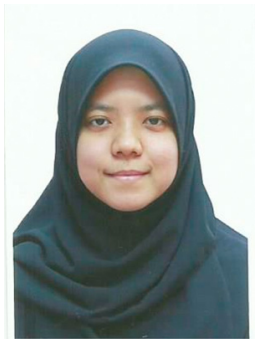

NURUL LIYANA LUKMAN HEKIEM Hreceived her B. Eng. and M. Eng. in Chemical Engineering from the University of Leeds, United Kingdom in 2018. She is currently pursuing her $\mathrm{Ph} . \mathrm{D}$ in electronic engineering at International Islamic University Malaysia (IIUM). Her research focuses on the sensing layer for acoustic wave sensors.

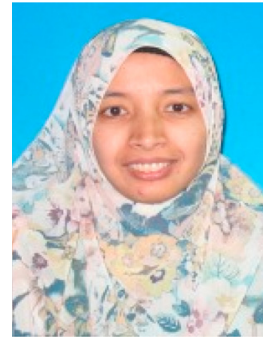

ALIZA AINI MD RALIB obtained her B. Eng in Computer and Information Engineering (Electronics) from International Islamic University Malaysia in 2006. Both her MSc and $\mathrm{PhD}$ in Electronics Engineering are also from IIUM in 2011 and 2016 respectively. She previously work at Intel Microelectronics Malaysia as layout design engineer from 2006-2009. From 2009 to 2016, she was a Research Assistant at Universiti Tenaga Nasional Malaysia and IIUM. Since 2016, she has been Assistant Professor with the Electrical and Computer Engineering Department, International Islamic University Malaysia. Her research interests include Micro Electro-mechanical (MEMS), CMOS-MEMS acoustic wave resonators, electroacoustic sensors, piezoelectric thin film and MEMS piezoelectric energy harvesting. Upon completion of her $\mathrm{PhD}$, she decided to work on the development of acoustic wave sensors for breath analysis as noninvasive solution for early detection of critical disease. Her work has been published both locally and internationally in more than 40 papers in journals and proceedings locally and internationally. She has been awarded IEEE Postgraduate Award of Excellence in Outstanding Project in MEMS and Nanoelectronics and outstanding volunteer award organized by IEEE Electron Devices Society Malaysia Chapter in 2016 and 2019 respectively. She is currently an executive committee of IEEE Electron Device Society (EDS) Malaysia Chapter since 2017 - 2021. -

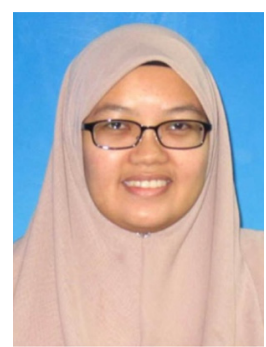

MAZIATI AKMAL BT MOHD HATTA is currently works at International Islamic University Malaysia (IIUM). Currently, she is a faculty member of the Department of Science in Engineering, Kulliyyah of Engineering, IIUM. She received the BSc and MSc in Materials Engineering from IIUM and obtained her Ph.D. in Materials Engineering (Advanced and Smart Materials) from Universiti Teknikal Malaysia Melaka (UTeM). Her research interests include advanced materials, electrochemical, electroceramics, and nanotechnology including piezoelectric ceramic-based materials, biomaterials, and rare-earthdoped ceramics. He also uses Comsol to solve some mathematical modeling problems related to energy harvesting applications. Currently, her research interest is development of piezoelectric devices (harvester, sensor and actuator) using biomaterials such as shrimp shells and fungi.

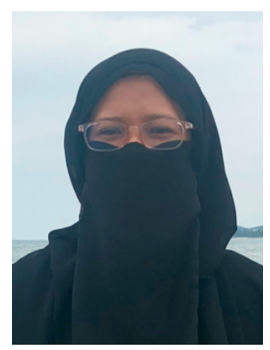

FARAH B. AHMAD is currently an academic in Kulliyyah of Engineering, International Islamic University Malaysia. She received her Ph.D. in Energy and Process Engineering at Queensland University of Technology (2016). She was the recipient of Denis Foster Chemistry/Chemical Engineering Award in 2016. Her current research is focused on sustainable processing in biofuel production and biorefineries, especially from lignocellulosic biomass; and biosensors including electrochemical- and piezoelectricbased sensors.

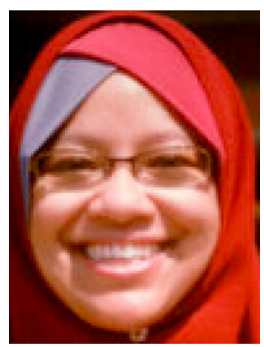

ANIS NURASHIKIN NORDIN currently work as professor at Department of Electrical and Computer Engineering, Faculty of Engineering, International Islamic University Malaysia (IIUM), Kuala Lumpur, Malaysia. She obtained her B. Eng. in Computer Engineering from IIUM and both her MSc and Doctor of Science in Microelectronics and VLSI from The George Washington University, Washington DC in 2003 and 2008 respectively. She has been teaching courses in Electronics Engineering since 2003. She has been awarded IEEE Senior Member. She has won IIUM's Most Promising Researcher Award in 2010 and IIUM's Most Outstanding Researcher Award in 2014. She has extensive international collaborative networks and has served as an invited researcher for Linkoping University, Sweden, City College of New York, USA, Griffith University, Australia and University of Twente, Holland. Her area of specialization is in the field of Micro-electro-mechanical Systems (MEMS). Upon completion of her PhD, she decided to work on developing biosensors that will reduce the pain burden of chemotherapy on patients. Her most innovative product to date is a personalized cancer chemotherapeutics kit, which can both select the best chemotherapy drug for the patient as well as its optimum dosage. She has also developed numerous micro-sized devices such as resonators and energy harvesters. Her novel innovations have been well received and have been awarded in both international and local exhibitions such as IENA in Nuremberg, British Invention Show in London. She currently holds two US-patents. Her work has been published both locally and internationally in more than 100 papers in journals and proceedings locally and internationally. 


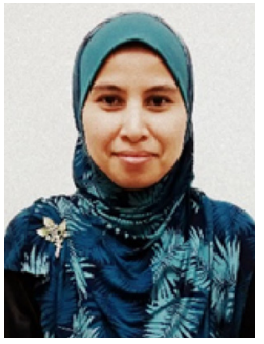

ROSMINAZUIN AB RAHIM currently works as an Associate Professor at Faculty of Engineering, International Islamic University Malaysai after finishing her $\mathrm{PhD}$ in Engineering (MEMS \& Nanoelectronics) from Institute of Microengineering and Nanoelectronics (IMEN), Universiti Kebangsaan Malaysia in 2012. Back in 1999, she was a former graduate from Universiti Sains Malaysia in Electrical \& Electronic Engineering (Microelectronics) before continuing her studies at Universiti Kebangsaan Malaysia in MSc. Microelectronics in 2004. She obtained an industrial exposure from Delphi Packard Electric (M) Sdn Bhd from1999

to 2001 where she worked as a Quality Engineer. Her research areas are related to MEMS device and fabrication where she was exposed to cleanroom-associated fabrication process while working on her PhD research on development of MEMS cantilever-based sensor. Her other research areas include piezoelectric energy harvester and biosensor.

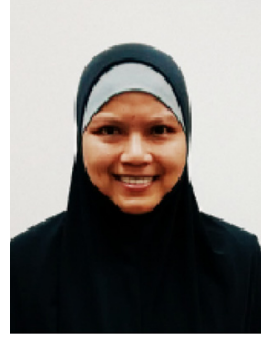

NOR FARAHIDAH ZA'BAH a former graduate of the Universiti Tenaga Nasional in Kajang, Selangor started her career as a Process Engineer in Silterra Malaysia, Kulim Hi Tech Park, Kedah where she provided processengineering support to the CMOS manufacturing team. In 2004, after receiving her MSc from Newcastle University, UK, she was appointed as a Lecturer at Universiti Tenaga Nasional. In 2007, she accepted an offer as a lecturer in International Islamic University Malaysia and a year later, she pursued her PhD in Newcastle University, UK. Her research was focusing on the fabrication of silicon nanowire using the top-down approach. She received her $\mathrm{PhD}$ in 2012 and currently, she is attached as an Associate Professor to the Department of Electrical and Computer Engineering, International Islamic University Malaysia, Kuala Lumpur. 